
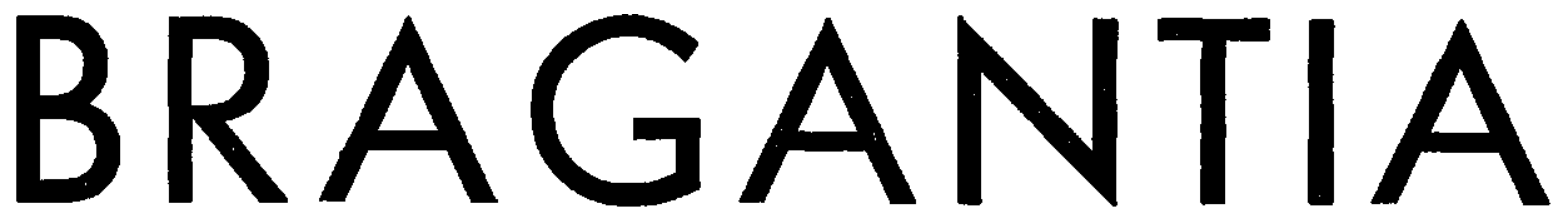

Boletim Técnico do Instituto Agronômico do Estado de São Paulo

\begin{tabular}{llll}
\hline Vol. 16 & Campinas, dezembro de 1957 & N. 23 \\
\hline \hline
\end{tabular}

\title{
ANATOMIA E DESENVOLVIMENTO ONTOGENÉTICO DE COFFEA ARABICA L. VAR. TYPICA CRAMER (*)
}

\author{
D. M. Dedecca
}

Engenheiro-agrônomo, Seção de Botânica, Instituto Agronômico

\section{R E S U M O}

O presente estudo anatômico de Coffea arabica L. var. typica Cramer tem por finalidade fornecer informações básicas necessárias ao estudo da anatomia comparada das principais espécies e variedades de cafeeiros, cultivadas no Estado de São Paulo.

Nesta primeira contribuição o autor realiza o estudo anatômico detalhado dos órgãos vegetativos e reprodutivos da variedade typica, não se limitando apenas à anatomia descritiva dos diversos órgãos, mas também, sempre que possivel, discutindo o desenvolvimento ontogenético das diversas partes do cafeeiro. No estudo da raíz e do caule procurou-se estabelecer a duração do desenvolvimento primário, assinalando o local de aparecimento, primeiramente do câmbio vascular e, posteriormente, do felógeno ou câmbio suberoso. Na discussão da anatonia das fôlhas mereceu especial atenção o estudo das domácias, sua morfologia e possível função. As flôres são estudadas detalhadamente nos seus diversos elementos. Nos capitulos referentes à anatomia do fruto e da semente, além do estudo puramente descritivo das suas estruturas são ainda discutidas as diversas modificaçōes verificadas durante o desenvolvimento do ovário e dos óvulos, respectivamente em fruto e seinentes.

\section{1 - INTRODUÇÃO}

Êste estudo, da anatomia de Coffea arabica L. var. typica Cramer, é o primeiro de uma série de trabalhos sôbre as diversas variedades e espécies de cafeeiros, principalmente os de maior importância econômica, que serão posteriormente estudados de uma maneira comparada, considerando-se como básicos os dados fornecidos pelo exame da variedade typica.

Muito embora a anatomia ocupe, no momento, um lugar de destaque no fornecimento de informações que conduzam os taxonomistas a um melhor julgamento da natureza e afinidades dos grupos vegetais, a sua aplicação como instrumento auxiliar na classificação das plantas não constitui uma novidade.

(*) Tese apresentada, em novembro de 1955, à Escola Superior de Agricultura "Luiz de Queiroz", da Universidade de Sáo Paulo, para a obtenção do título de Doutor em Agronomia.

Pela ajuda prestada nas diversas fases dêste trabalho, o autor apresenta os seus agradecimentos às seguintes pessoas: Dr. Geraldo C. Melo Ayres, Sr. Theophilo G. Cyrino, Dna. Mary O. Boock, Srtas. Zorah de Mello e Adelaide Botignon.

Recebido para publicaçăo em 13 de fevereiro de 1957. 
Bailey (5) acentua êsse pormenor e lembra que, na primeira edição de "Die natürlichen Pflanzenfamilien", Engler fizera eficiente uso dos característicos anatômicos na divisão da família Icacinaceae, o mesmo acontecendo com Pax ao estudar a família Monimiaceae, para não falar no valioso auxílio que o estudo da morfologia dos grãos de pólen proporcionou a Lindau na caracterização dås sub-famílias e tribos de Acanthaceae. Portanto, o entusiasmo que atualmente se nota entre os chamados "neo-morfologistas", pelo emprêgo de novos métodos e pontos de vista, como por exemplo, o uso das evidências fornecidas pela anatomia na solução dos problemas apresentados pela taxonomia, nada mais é do que um renovado interêsse em tôrno de fatos já de longa data postos em uso. E todo e qualquer ceticismo, com relação a esta afirmativa, por certo deixaria de existir ante uma pesquisa minuciosa através da vasta literatura botânica do século XIX, caso fôssem insuficientes os significativos exemplos acima citados.

No Instituto Agronômico, em Campinas, uma equipe de pesquisadores vem há cêrca de 20 anos dedicando-se ao estudo do cafeeiro, Coffea arabica L., suas variedades e espécies afins, realizando trabalhos nos setores da morfologia, citologia, genética, fisiologia, no que se refere às pesquisas básicas, e na elucidação dos problemas culturais, no campo das aplicações práticas.

Considerando-se que as pesquisas citológicas são pràticamente da mesma natureza que as da anatomia, pode-se realmente dizer que os estudos anatômicos do cafeeiro tiveram, neste estabelecimento de pesquisas, o seu início através dos trabalhos conduzidos por W. G. Houk e A. Carvalho, no período de 1935-38, quando o primeiro técnico chefiou a Seção de Botânica. Às suas pesquisas seguiram-se outros estudos citológicos dos cafeeiros, realizados por Mendes $(28,29)$ e outros técnicos da Seção de Citologia.

Embora estudado intensivamente sob outros aspectos, o cafeeiro ainda não fôra alvo de estudos anatômicos pròpriamente ditos; Krug, Mendes e Carvalho (25), ocupando-se da sua morfologia exterior, descreveram em forma de monografia 26 variedades da espécie $C$. arabica L., fornecendo informações básicas para um amplo programa de melhoramento do cafeeiro.

$O$ estudo, que ora se inicia, sôbre a anatomia de algumas dessas variedades, tem por finalidade suplementar as informações obtidas no campo da morfologia exterior e, dêste modo ,tornar mais sólidos os conhecimentos sôbre a natureza dessas variedades.

Uma rápida revisão da literatura especializada demonstra que o gênero Coffea tem sido estudado contìnuamente por diversos autores, do ponto de vista anatômico. Marchand, segundo citação de De Wildeman (39), em 1864, publicou estudos organográficos sôbre algumas espécies do gênero Coffea, e particularmente sôbre o desenvolvimento ontogenético da flor de C. arabica L., podendo ser 
consiclerado como o pioneiro neste setor de pesquisas. De Wildeman (39), em 1903, dedicou particular atenção ao estudo das domácias da fôlha do cafeeiro, e em 1941 publicou uma extensa revisão do gênero Coffea L., analisando-o sob diferentes aspectos, morfológico, anatômico etc.. Solereder (35), em 1908, e mais recentemente Metcalf e Chalk (31), resumindo as informações sôbre a anatomia das Rubiáceas citam diversos característicos do gênero Coffea. Mariani (27), também em 1908, contribuiu com valioso estudo sôbre a anatomia das fôlhas, pesquisando a estrutura dêstes órgãos em 51 espécies e 5 variedades de cafeeiros. Von Faber (12), em 1912, realizou pesquisas morfológicas e fisiológicas na flor do cafeeiro, acentuando o modo de formação e a estrutura do endosperma. Bitancourt (6), no Brasil, em 1923, publicou algumas informações sôbre a anatomia dos órgãos vegetativos do cafeeiro. Freire (17), também no Brasil, no período de 1934-37 publicou resumidos artigos sôbre a constituição histológica de algumas espécies e variedades de cafeeiros. Houk $(20,21)$, em 1936 e 1938, Graner (18, 19), em 1936 e 1939, Fagerlind (13), em 1939, Mendes (28), em 1941, deram à publicidade os resultados que obtiveram nos seus estudos sôbre a estrutura do óvulo, o seu desenvolvimento em semente, cuidando particularmente da formação e estrutura do endosperma. Der Meulen (9), em 1939, realizou interessantes pesquisas sôbre a estrutura e o desenvolvimento periódico dos botões florais de diversas espécies do gênero Coffea. Varossieau (38), em 1940, estudou o desenvolvimento ontogenético do caule e das fôlhas de algumas espécies de cafeeiro. Finalmente, Chevalier (7) publicou um volumoso relatório sôbre a sistemática dos cafeeiros de todo o mundo, utilizando-se em grande escala dos característicos anatômicos do caule, fôlha, fruto e semente.

\section{2 - MATERIAL E MÉTODOS}

Para o estudo anatômico da raíz, do caule e das fôlhas, utilizaram-se plantas novas de Coffea arabica L. var. typica Cramer, obtidas a partir de sementes fornecidas pela Seção de Genética do Instituto Agronômico e pertencentes à progênie 12-9-2. Estas sementes foram inicialmente postas para germinar em caixas de Petri contendo papel de filtro umedecido, e posteriormente transferidas para caixas com terra ou canteiros, no interior de estufas. Para o estudo da anatomia dos órgãos reprodutivos colheram-se botões florais, flôres, frutos novos e maduros e sementes de cafeeiros da mesma progênie, existentes na coleção da Seção de Café, na Estação Experimental Central do Instituto Agronômico.

$\mathrm{Na}$ coleta do material vegetativo os diversos órgãos da planta foram secionados em fragmentos de um centímetro, e êstes numerados na ordem do seu desenvolvimento; as lâminas obtidas de cada bloco foram numeradas separadamente a fim de se poder, mais 
tarde, localizar a situação de um determinado corte, uma vez conhecida a espessura com que foram realizados os referidos cortes.

A fórmula de "Craf", modificada por Randolph (33), foi a que melhor resultado ofereceu para a fixação do material em estudo, operação esta normalmente realizada durante 24 horas. Em seguida procedeu-se à desidratação segundo a série álcool etílico - álcool butílico, infiltração em parafina e seção em micrótomo do tipo Minot, rotativo, tendo a espessura dos cortes variado, de um modo geral, entre 15-20 micros.

O material de raíz foi colorido em hematoxilina; para os demais órgãos utilizou-se uma solução de corante da seguinte composição :

sol. aq. de hematoxilina a $0,5 \% \ldots \ldots$. . 6 partes

sol. aq. de vermelho neutro a 1\% ... . 2 partes

sol. sat. de floroglucina em $\mathrm{HCl}$ a $18 \%$. 1 parte

A coloração foi realizada durante $24-48$ horas; a contra-coloração foi conduzida segundo a série de álcool-xilol; finalmente, as lâminas foram montadas em bálsamo do Canadá.

Para o estudo das substâncias ergásticas, das células, à saber, amido, oxalato de cálcio etc., utilizou-se material recém-colhido e secionado; as fibras que constituem o endocarpo e a película prateada da semente foram estudadas mediante a maceração dêstes tecidos durante 20-30 minutos na solução de Jeffrey, e montadas diriretamente em uma gôta de uma solução saturada de floroglucina em $\mathrm{HCl}$ a $18 \%$.

No estudo das domácias e do suprimento vascular dos diversos verticilos florais, as fôlhas e as flôres foram, respectivamente, clarificadas numa solução aquosa de $\mathrm{NaOH}$ a $5 \%$ e coloridas com safranina a $1 \% \mathrm{em}$ álcool $50 \%$, e em seguida trabalhadas segundo a série de álcool-xilol; finalmente, foram montadas em bálsamo do Canadá.

$O$ estudo das lâminas foi realizado em microscópio Leitz-Ortholux, modêlo II, de tubo combinado, mono-binocular, com aumento de até 1700 vêzes. Os desenhos são na sua quase totalidade originais e foram realizados em câmara escura, com auxílio de um espêlho de projeção adaptável ao microscópio Leitz-Ortholux, estando os aumentos utilizados discriminados junto às gravuras. As ilustrações C - I, na estampa 2, são adaptadas do trabalho de Der Meulen (9).

\section{3 - ANATOMIA DOS ÓRGÃOS VEGETATIVOS 3.1 - RAfZ}

De acôrdo com Franco e Inforzato (16), o cafeeiro não apresenta um sistema radicular primário típico, visto que nos seus estudos êsses autores tiveram a oportunidade de observar a grande 
influência que as propriedades físicas e químicas do solo exercem sôbre as raízes do cafeeiro. Acentuam ainda, os mesmos autores, cue a única afirmativa de ordem geral que pode ser feita é a de que a raíz primária do cafeeiro não vai além de $0,5 \mathrm{~m}$ de profundidade. Essa raíz primária, nas condiçoes normais de cultura, ramifica-se abundantemente, dando formação a um volumoso conjunto de raízes laterais, que se aprofundam no solo e que, dependendo das características dêste, podem atingir 2,5 e mesmo $3 \mathrm{~m}$ de profundidade.

\section{$3.1 .1-$ ÁPLCE DA RAIZ}

Cortes longitudinais da raíz põem em evidência as suas diferentes zonas (fig. 1 e est. 1 -A) ; a parte verdadeiramente terminal é ocupada por uma coifa (cf), muito bem desenvolvida, de 400-750 micros de comprimento e que reveste o meristema apical (m.a.), que é neste caso sub-terminal, protegendo-o contra as asperezas e o dessecamento do solo. As cédulas que constituem a coifa apresentam-se hialinas e são grosreiramente isodiamétricas na forma, nas porções distantes da região meristemática, ao passo que as cédulas laterais tendem a ser relativamente alongadas no sentido do eixo da raíz.

Em localização sub-terminal encontra-se o meristema apical da raíz, ou promeristema (m.a.) que é, na radícula, do tipo aberto e representado por uma zona meristemática transversal, que ocupa todo o ápice da raíz. Da atividade e divisão de suas células vão se oríginar todos os tecidos que constituem o corpo da raíz, bem como a adição, para o exterior, de novas células para a coifa. A partir da divisão das células da região marginal dêste meristema transversal formam-se novas porções laterais da coifa e as células iniciais da camada dermatogênica (dr) e do periblema $(\mathrm{pb})$. Por sua vez, as células da camada dermatogênica tornam-se alongadas no sentido do eixo da raíz, e mantendo a sua unidade através de repetidas divisões anticlinais, vão dar origem à epiderme da raíz (epid.). As células do periblema, a princípio compactamente unidas entre si, sem deixar espaços intercelulares, após um limitado período de atividade meris-

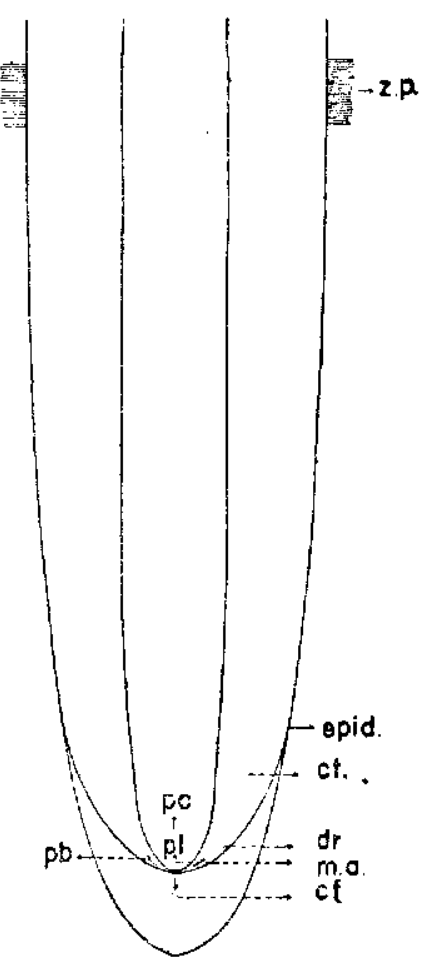

Figura 1. - Desenho esquemático do ápice da raíz, segundo um corte longitudinal $(60 \mathrm{X})$ : cf $=$ coifa; m.a. $=$ meristema apical; $\mathbf{d r}=$ camada dermatogênica; $\mathbf{p b}=$ perible$\mathrm{ma} ; \mathbf{p l}=$ pleroma; pc = procâmbio; ct = cortex; epid. = epiderme; z.p. $=$ zona pilífera. temática, entram em diferençação e vão constituir o córtex ou região cortical da raíz, caracterizada pelas suas células de forma isodia- 
métrica, de paredes delgadas, e a presença de numerosos espaços intercelulares. A camada de células mais interna e que tem origem a partir do periblema vai constituix o endoderma.

Das células centrais do meristema apical formam-se, para o exterior da raín, os novos tecidos da região mediana da coifa; para o interior, graças às continuas divisões segundo plenos transvorsais, têm origem as células que vão constituir o pleroma (1). Dessas células, que se dividem repetidanente segundo planos tangenciais, tem formação o procâmbio (pc); as células procambiaís entram em diferençação numa zona situada mais ou menos a $3,5 \mathrm{~mm}$ do ápice da raíz (fig. 2). Notamse então os primeiros elementos do protoxilema $(\mathrm{px})$, que se colocam espaçados entre si segundo ângulos variáveis de $60^{\circ}$ (nas raízes hexárquicas) a $33^{\circ}$ aproximadamente (nas raízes que apresentam 11 feixes lenhosos). A esta altura, contudo, os elementos do protoxilema são ainda de paredes relativamente delgadas, e os espessamentos se-

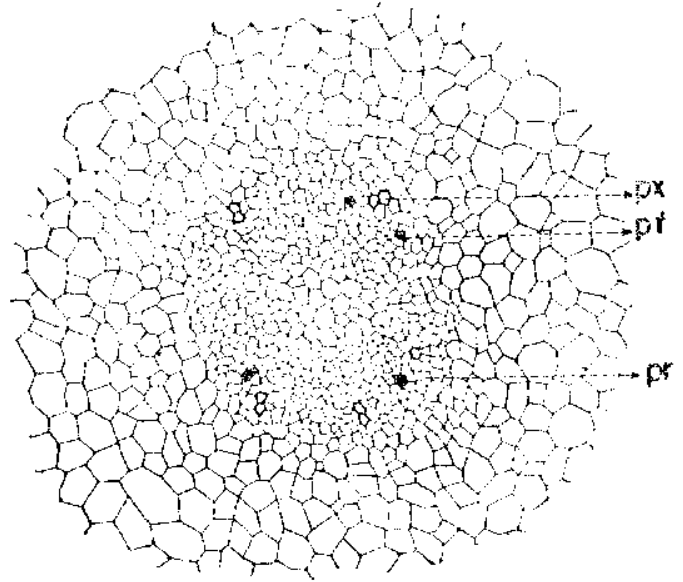

Figura 2. - Corte transversal da raíz, aproximadamente a $3,5 \mathrm{~mm}$ do ápice, mostrando o periciclo (pr) e a diferençação dos primeiros elementos do protoxilema (px) e do protofloema (pf) (390 X). cundários das suas paredes sònente são revelados em cortes praticados a partir de um centímetro do ápice da raíz (fig. 3).

Por entre os elementos do protoxilema aparecem as iniciais do protofloema (pf), reconhecidas principalmente pelo aspecto plasmolizado do seu citoplasma, como resultado da ação dos reagentes químicos e dos corantes. Envolvendo o protoxilema e o protofloema e logo abaixo do endoderma, aparese o periciclo (pr), representado por uma ou duas camadas de células (fig. 2).

O xilema e o floema primários diferençam-se centripetamente, isto é, a maturação dos seus elementos tem inicio na borda mais externa dos respectivos feixes e progride num sentido centrípeto. Da contínua diferenças̃ão do xilena primário, nesse sentido, resulta. a formação de um massiço centrai sólido de xilema, que contere à raiz uma estrutura radial tipicamente proto-estélica (fig. 4).

\subsection{2 - ISTRUTURÁ PRIMARTA}

No término do seu desenvolvimento primário, a raíz da variedade typica apresenta-se com uma estrutura poliárquica, proto-estélica, exárquica, exibindo nos cortes transversais praticados a $4 \mathrm{~cm}$ do ápice, as seguintes regiões ou zonas de tecidos (fig. 4), consideradas de fora para dentro: 
Epiderme (epid.) - constituida de uma só camada de células compactamente unidas entre si, e que somente se dividem segundo planos anticlinais, alongadas ou algo retanguiares na forma, de parede tangencial externa bastante espêssa e de paredes radiais retas ou levemente inclinadas, cuja espessura diminui progressivamente para o interior. Numa região distal do ápice da $r$ aí $z$, aproximadamente a $4 \mathrm{~cm}$ dêste ápice, tem início a zona pilífera ou dos pêlos absorventes fig.

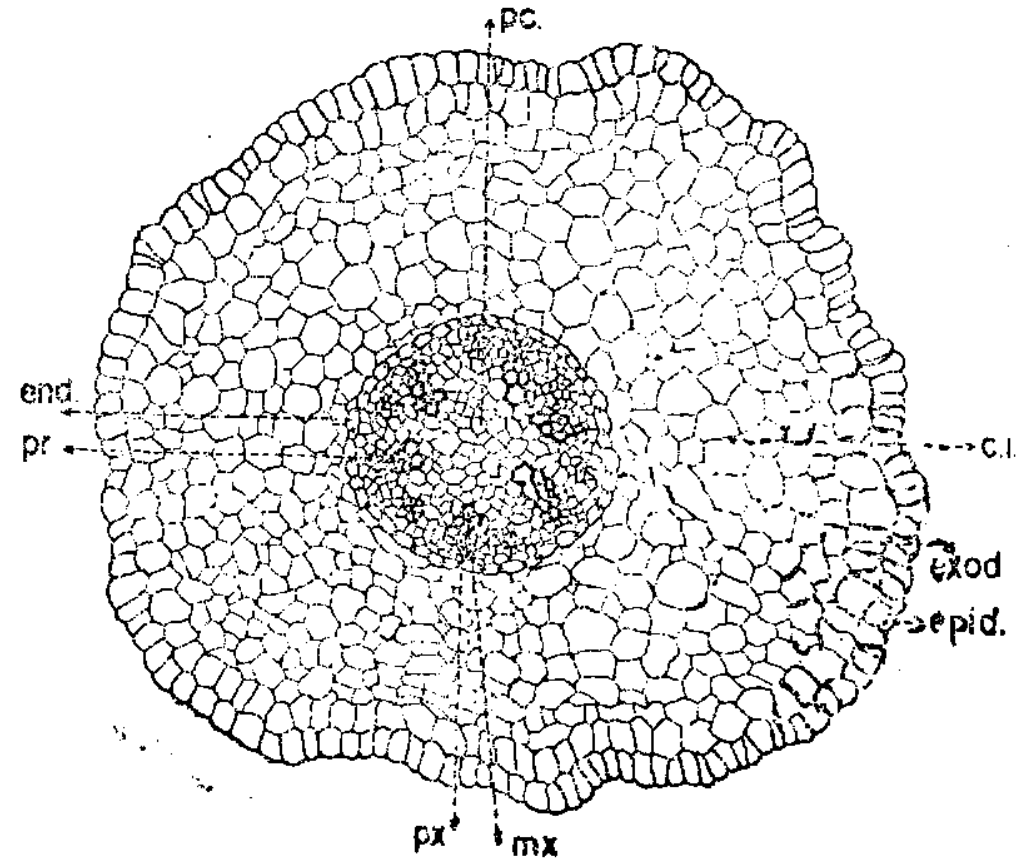

Figura 3. - Corte transversal da raíz, cêrca de $1 \mathrm{~cm}$ do apice, exibindo os feixes lenhosos e liberianos já compietamente diferençados $(80 \mathrm{X})$. c.i. $=$ córtex imaturo; end. = endoderma; exod. $=$ exoderma; epid. = epiderme; $\mathbf{m x}=$ metaxilema; $\mathbf{p c}=$ procâmbio; $\mathbf{p r}=$ periciclo; $\mathbf{p x}=$ protoxilema.

1). Nesta região as células epidérmicas dão origem aos pêlos capilares ou absorventes (p.a.), que são numerosos, na sua maioria unicelulares, medindo os maiores cêrca de 90 micros.

Córtex (ct) - a zona cortical da raíz é uma região bastante extensa apresentando-se constituida de 6-8 camadas de células tipicamente parenquimatosas, isto é, isodiamétricas na forma, de paredes delgadas e deixando visíveis espaços entre si. Exteriormente o córtex apresenta uma camada de células mais compactamente unidas entre si e de paredes suk erizadas, constituindo um exoderma (exod.), não muiL to característico. As células 
das camadas seguintes do córtex são relativamente grandes e o seu tamanho diminui visivelmente nas camadas mais interiores. Um característico de muitas células corticais é a presença do oxalato de cálcio, quer sob a forma de grânulos pequenos e pouco numerosos, semelhantes a uma areia fina, quer sob a forma de densas massas de pequenos cristais (m.c.), que parecem ter tido origem a partir da aglomeração de numerosos cristais granulares. A localização dêstes cristais de oxalato de cálcio parece revestir-se de uma certa especificidade, pois percebe-se, em cortes longitudinais, estarem presentes em células localizadas na mesma fileira vertical.

Endoderma (end.) - o limite interno do córtex está representado por uma camada contínua de células compactamente unidas entre si e que, em corte transversal, aparecem como um distinto anel rodeando o estelo. Esta camada é o endoderma e a sua identificação não oferece dificuldade devido à coloração forte evidenciada pelas paredes radiais das células, motivada pela deposição de material suberoso, constituindo as chamadas estrias de Caspary. As células que constituem o endoderma são vivas e mantêm-se ativas $\mathrm{e}$ dotadas de uma acentuada capacidade de reativar o desenvolvimento, o que é evidenciado por ocasião do aparecimento das raízes laterais (fig. 5), e durante os primeiros estágios

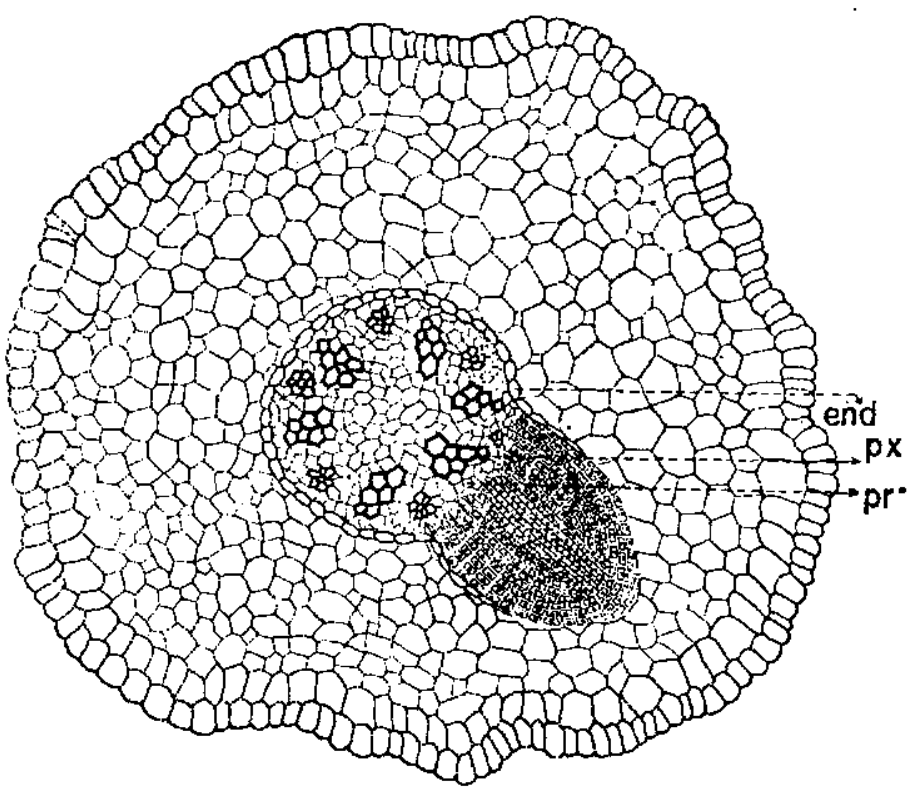

Figura 5. - Corte transversal da raíz, aproyimadamente a $1,5 \mathrm{~cm}$ do ápice, mostrando a origem endogena das raizes Iaterais, a partir de células periciclicas situadas na borda externa do protoxilema $(80 \mathrm{X})$. end. $=$ endoderma; $\mathbf{p r}=$ periciclo; $\mathbf{p x}=$ protoxilema.

do crescimento secundário da raíz. O endoderma em ambos os casos mantém-se contínuo, e graças às divisões anticlinais de suas células, amolda-se ao aumento do estelo em diâmetro.

Cilindro vascular - o cilindro vascular ou estelo está representado exteriormente por 1-2 camadas de células que constituem o periciclo (pr). Tendo se diferençado relativamente cedo durante a histogênese da raíz, o periciclo aparece em contato direto com o protofloema e o protoxilema e mantém a sua capacidade meristemática por muito tempo; a partir de suas células irão formar-se as raizes laterais, porções do câmbio vascular e o câmbio suberoso ou felógeno. 
Internamente ao periciclo aparecem os feixes lenhosos e liberianos, que originalmente exibiam uma posição radial e alternada (fig. 3). Nas porções mais velhas da raíz, os diversos feixes lenhosos, originalmente distintos entre si, apresentam-se unidos e dão formação a um massiço central de tecido lenhoso que confere à raíz a sua estrutura tìpicamente proto-estélica (fig. 4). É variável o número de feixes de xilema e de floema primários nas raízes dos diferentes indivíduos da variedade typica, ou nas raízes de um mesmo indivíduo. O menor número observado foi 6 , o que confere à raíz uma estrutura hexárquica; porém, como são freqüentes as raízes com $7,8,9$ e 11 feixes de xilema e floema primários, é preferível designar tal raíz como poliárquica

O protoxilema está constituído principalmente de fibras lenhosas não septadas, traqueídes e vasos; as paredes dos traqueídes exibem predominantemente espessamentos secundários do tipo espiralado; os vasos são pequenos no comprimento e no diâmetro transversal, de placa perfurada simples e paredes laterais com espessamento pontuado a alternado. No metaxilema êsses mesmos constituintes estão presentes, acrescentando-se a êles uma regular abundância de parênquina lenhoso, cujas células apresentam-se retangulares em seção e de paredes espêssas com pontuações simples.

O floema primário parece ser exclusivamente constituído de tubos crivosos, células companheiras e parênquima liberiano.

\subsection{3 - RAÍZES LATERAIS}

As raízes laterais, de origem endógena, têm formação a partir de células pericíclicas situadas na borda exterior do protoxilema. Como a raíz de C. arabica L. var. typica Cramer é poliárquica, formam-se tantas fileiras verticais de raízes laterais quantos são os feixes lenhosos, isto é, $6,7,8,9$, e 11.

A raíz lateral em formação (fig. 5) desenvolve-se ràpidamente é, à medida que progride e caminha centrìfugamente através das camadas do parênquima cortical, é acompanhada pelo endoderma que multiplicou as suas células segundo planos anticlinais e dêste modo ajusta-se àquele desenvolvimento que se projeta para fora do cilindro central.

Em pouco tempo, quando se encontra na parte média do parếnquima cortical, a raíz lateral em formação apresenta-se perfeitamente constituída, sendo já visíveis uma coifa, camada demartogênica, periblema e pleroma.

\subsection{4 - ESTRUTURA SECUNDËIA}

O crescimento secundário da raíz tem início em uma região pouco distante do ápice. Cortes transversais praticados a cêrca de $5 \mathrm{~cm}$ do ápice põem em evidência o aparecimento do câmbio vascular e dos seus tecidos derivados, xilema secundário para o 
segundo planos anticlinais predominantemente, exceto na regiăo de nascimento de uma fôlha ou de uma gema. Envolvido pela túnica, acha-se um aglomerado irregular de células, sem planos definidos de divisão e que constitui o corpo (cp). A túnica e o corpo representam, respectivamente, zonas de crescimento em superfície e em volume.

\subsection{2 - ESTRUTURA PRIMÁRIA}

Seções transversais do caule exibem um contôrno arredondado ou, mais comumente, retangular e apenas algo arredondado nos lados menores do retângulo. O estudo de seções praticadas a 800-

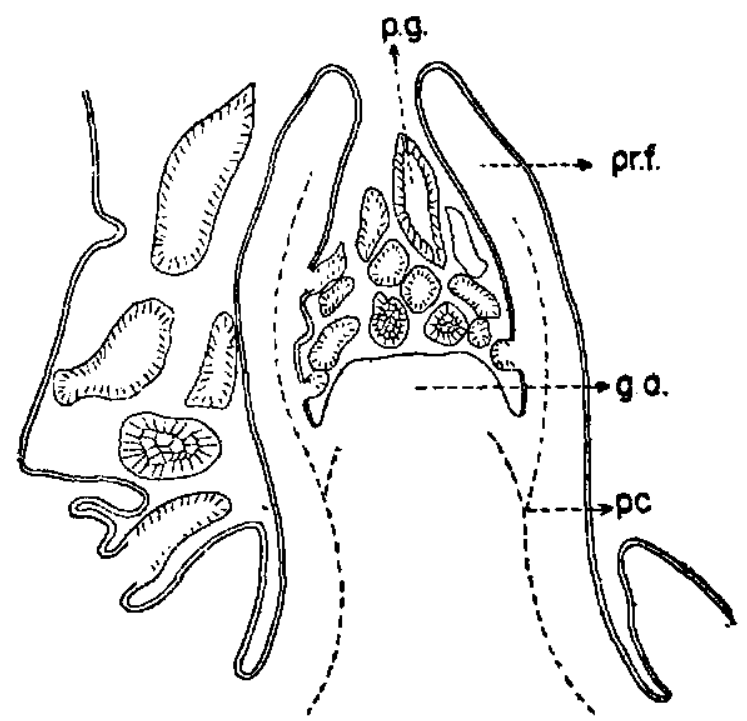

Figura 8. - Desenho esquemático de um corte longitudinal do caule, mostrando a gema apical e os primórdios foliares $(40 \mathrm{X})$. g.a. $=$ gema apical; pe $=$ procâmbio; p.g. $=$ pêlos glandulares; pr.f. = primórdio foliar. -900 micros da gema apical já revela a diferençação das diversas zonas de tecidos; esta diferençação prolonga-se por um tempo relativamente longo, pois, sòmente cortes praticados a uma distância de $2,5 \mathrm{~cm}$ da gema apical é que exibem uma diferençação mais adiantada de todos os tecidos que constituem a estrutura primária do caule. Esta estrutura é a dada a seguir (fig. 10, $A$ e $B$ ).

Epiderme - unisseriada, formada de células epidérmicas típicas e estomas, e desprovidas de tricomas de qualquer espécie. Revestindo a epiderme aparece uma delgada cutícula (c).

Córtex - representado por 7-9 camadas de cédulas parenquimatosas (que entre si deixam espaços visíveis), ricas em cloroplastos e muito comumente encerrando grãos de amido e massas compactas de pequenos cristais granulares de oxalato de cálcio. As camadas mais externas do córtex já exibem um início de espessamento celulósico nos ângulos de união das células, constituindo os primeiros indícios de um colênquima angular (col.), cuja diferençação completa é atingida bem posteriormente. A camada cortical mais interna apresenta-se com as mesmas características das camadas exteriores e definitivamente não exibe nas paredes radiais e transversais de suas células as deposições suberosas que constituem as estrias de Caspary; por êste motivo não se pode dizer que o caule apresenta um endoderma típico. 
Cilindro vascular - diretamente em contato com a camada mais interna do parênquima cortical está localizado o periciclo, que se apresenta sob a forma de duas camadas de células, a maioria das quais já exibe grandes espessamentos secundários nas suas paredes e constituem verdadeiras fibras. Envolvido pelo periciclo encontra-se um grande número de feixes vasculares, do tipo colateral, que a princípio eram distintos entre si mas que em virtude

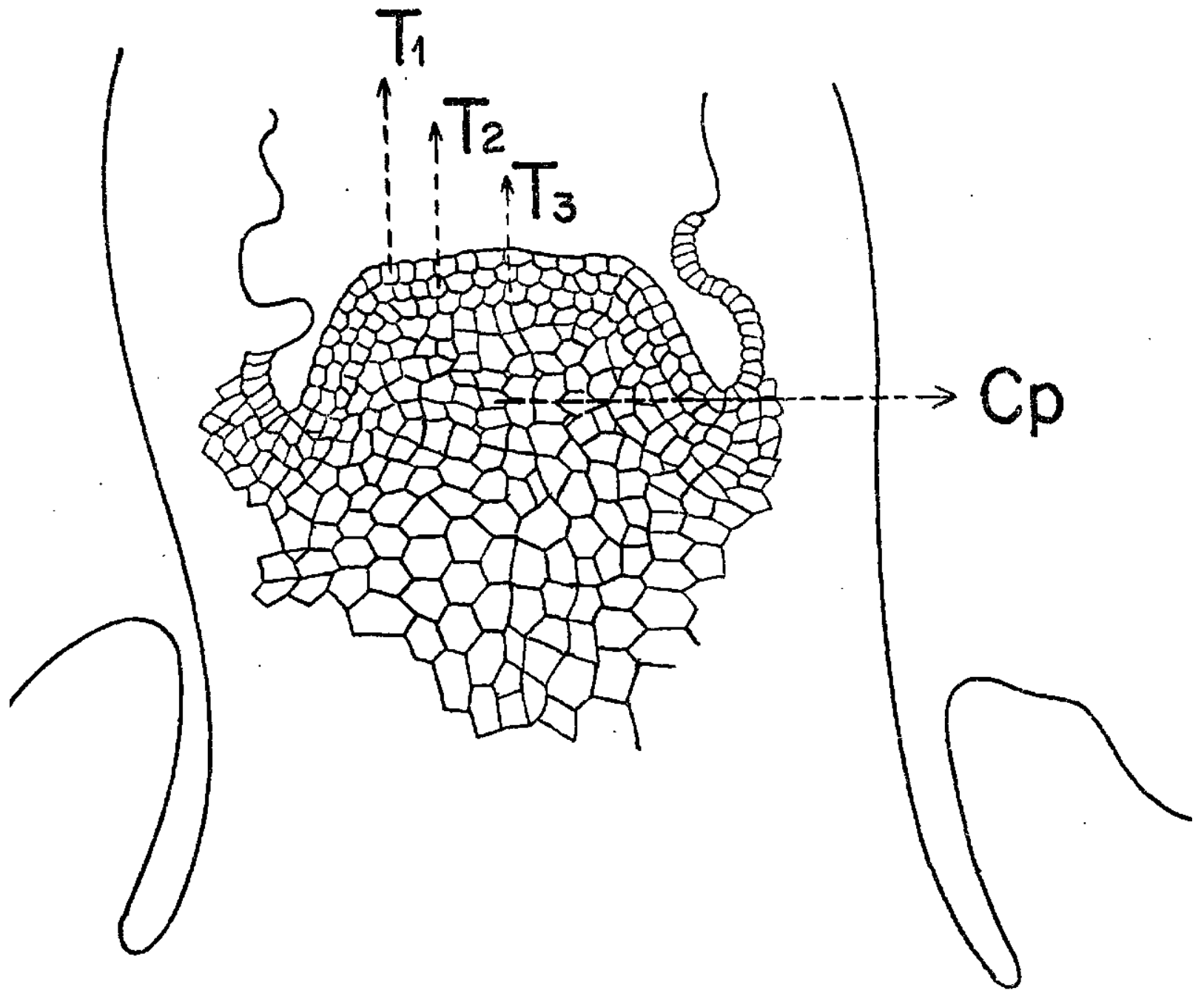

FIgURA 9. - Gema apical do caule, segundo um corte longitudinal, exibindo sua estrutura zonada $(120 \mathrm{X}) . \mathbf{T}=$ túnica; $\mathbf{C p}=$ corpo.

do seu desenvolvimento se uniram lateralmente, de tal modo que o sistema vascular se apresenta constituído por um cilindro contínuo de floema primário envolvendo outro cilindro contínuo de xilema primário. No interior do cilindro vascular encontra-se uma região extensa de tecido parenquimatoso, de células grandes, paredes delgadas e visiveis espaços intercelulares. Êste tecido, que ocupa a região central do caule, é a medula (med.), as suas células apresentando as mesmas inclusões das células parenquimatosas do 
córtex, ou sejam, grãos de amido e massas de pequenos cristais granulares. Apresentando os característicos atrás mencionados 0 caule, ao terminar o seu desenvolvimento primário, exibe uma estrutura sifono-estélica, endárquica, ectofloica.

A diferençação e a maturação radial e progressiva do xilema primário se processam segundo um sentido centrifugo (xilema endárquico); o protofloema, ao contrário, se diferenca centripetamente, de modo que os elementos liberianos mais velhos são encontrados em contato com o peviciclo. Na constituicão do flocma primáxio entram tubos crivosos, células companheiras e, mais abundantemente, parênquima likeriano.

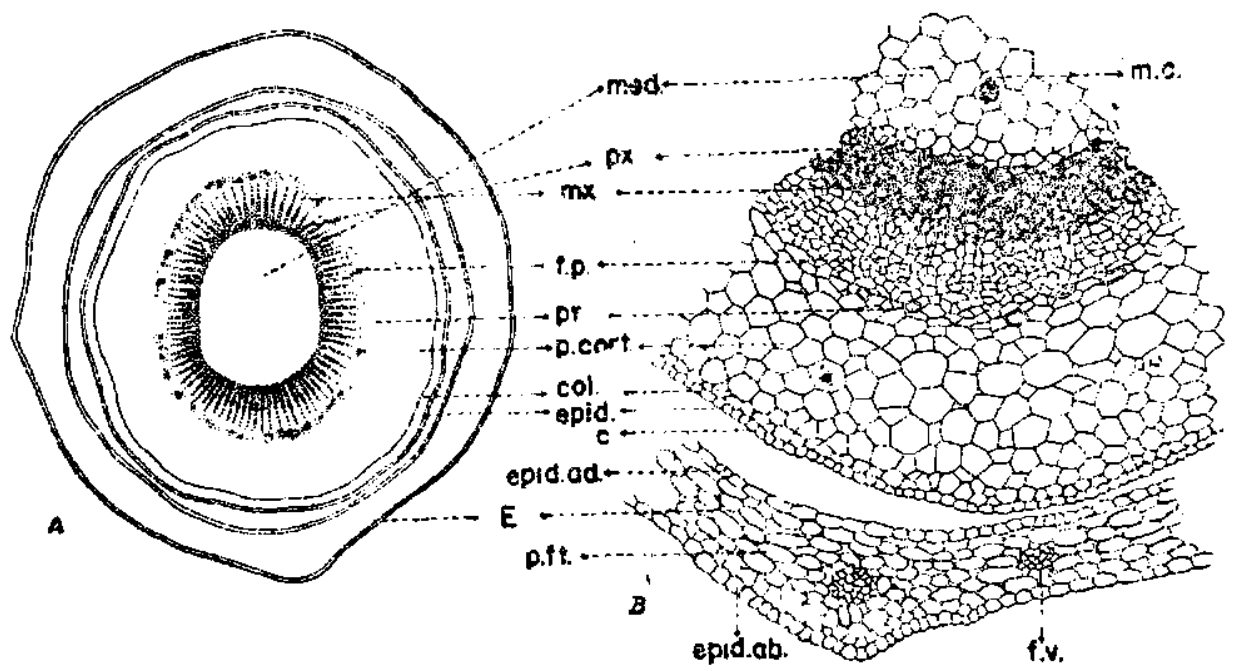

Figura 10. - A - Estrutura primária do caule: - desenho esquemático de um corte praticado cêrca de $2 \mathrm{~cm}$ do ápice, sendo também visíveis as estípulas $(24 \mathrm{X})$. c $=$ cutícula; col. $=$ colênquima; epid. = epideime do caule; epid. ab. = epiderme abaxial da estipula; m.c. = massas de cristais; med. $=$ medula; $\mathbf{m x}$. = metaxilema; epid. ad. = epiderme adaxial da estipula; $\mathbf{E}=$ estípula; $\mathbf{1 . p .}=$ floerna primário; f.v. $=$ feixe vascular; p.cort. = parênquima cortical; p.ft. = parênquima fotossintético; $\mathbf{n r}=$ pericicio; $\mathbf{p x}=$ protoxilema; $B-\mathrm{De}-$ talhes histológicos de um setor do mesmo corte $(60 \mathrm{X})$.

o protoxilema, ou seja, a primeira porção de xilema primário a se diferençar, ocupa uma posição bastante interna, no limite com a medula. As porções sucessivas de rilema que se diferençam para o exterior constituem o metaxilema. De um modo geral o xilema primário apresenta-se constituído de vasos anelados e traqueides, parênquima lenhoso e fibras lenhosas não septadas.

\subsection{3 - ESTRUTURA SECUNDARIA}

O crescimento secundário do caule tem início numa região localizada aproximadamente a $2,5 \mathrm{~cm}$ da gema apical. Células procambiais localizadas entre o metaxilema e o metafloema em cada 
feixe vascular continuam a se dividir segundo planos tangenciais e dão formação às primeiras porções de câmbio vascular, que assume um aspecto estratificado. Posteriormente, células situadas entre essas porções do câmbio vascular passam a exibir uma atividade meristemática e como resultado disto formam-se porções de câmbio interfascicular; êste logo se une às porções de câmbio fascicular, formando-se finalmente um cilindro contínuo de câmbio. Entrando em repetidas divisões tangenciais o câmbio vascular vai dar origem ao xilema secundário, constituído pelos elementos que se diferençam centrìpetamente, ao passo que os elementos diferençados para o exterior da zona cambial vão constituir o floema secundário (figs. 11 e 12). Em cortes tangenciais tornam-se visiveis os raios lenhosos e os raios liberianos que se apresentam uni- ou bisseriados. Os raios medulares apresentam-se nessas seções com a forma de losangos estreitos e alongados, em número de 8-10 células superpostas em fileira vertical. Segundo Chevalier (7), muitas dessas células que separam os feixes lenhosos encerram cristais prismáticos e a constância dessas inclusões em tôdas as espécies de cafeeiros da Seção Eucoffea pode ser considerada como um característico para a Seção.

Cortes tranversais praticados nas regióes que já possuem um câmbio vascular em atividade apresentam uma estrutura um pouco diferente da estudada no

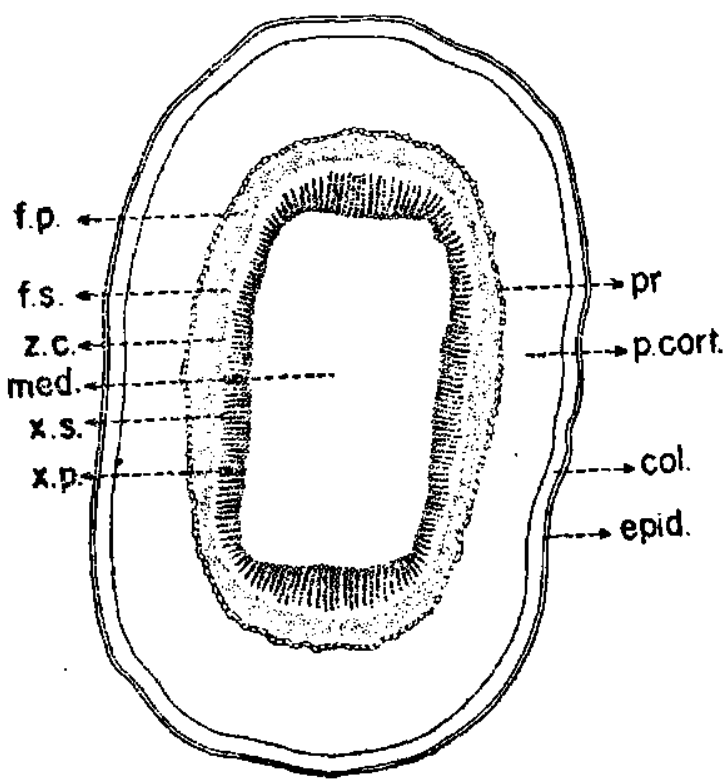

FIgURa 11. - Estrutura secundária do caule: - desenho esquemático de corte transversal praticado cêrca de $2,5 \mathrm{~cm}$ do ápice, mostrando o aparecimento do câmbio vascular e os tecidos secundários que dêle se originam $(17 \mathrm{X})$. col. = colênquima; epid. $=$ epiderme; f.p. = floema primário; f.s. $=$ floema secundário; med. $=$ medula; p.cort. $=$ parênquima cortical; $\mathbf{p r}=$ periciclo: x.p. $=$ xilema primário; $\mathbf{x . s . ~}=$ xilema secundário; z.c. = zona cambial. desenvolvimento primário do caule. Exteriormente, a epiderme nada apresenta de novo; a região cortical, contudo, já revela algumas modificações, pois, além de apresentar-se muito mais desenvolvida, exibe ainda uma composição heterogênea. Logo abaixo da epiderme, constituindo as camadas mais externas do córtex, aparecem 3-4 camadas de tecido colenquimatoso, constituído de células poligonais, pequenas, compactamente unidas entre si e que mostram espessamentos celulósicos pronunciados nos ângulos de confluência das células, constituindo, portanto, um colênquima com espessamento angular típico. 
Em seguida, o córtex tem continuidade sob a forma de 10-12 camadas de células parenquimatosas que deixam grandes espaços entre si, e que encerram grãos de amido e as inclusões de oxalato de cálcio já mencionadas. $O$ endoderma não é distinto e à camada cortical mais interna segue-se o periciclo, representado por duas camadas de fibras. O floema primário está representado mais abundantemente por um parênquima liberiano, cujas células comumente exibem as inclusões do oxalato de cálcio sob a forma de massas de cristais granulares. Por entre as células do parênquima liberiano aparecem grupos de tubos crivosos e células companheiras. 0 floema secundário recém-formado é seguido pela zona cambial, de

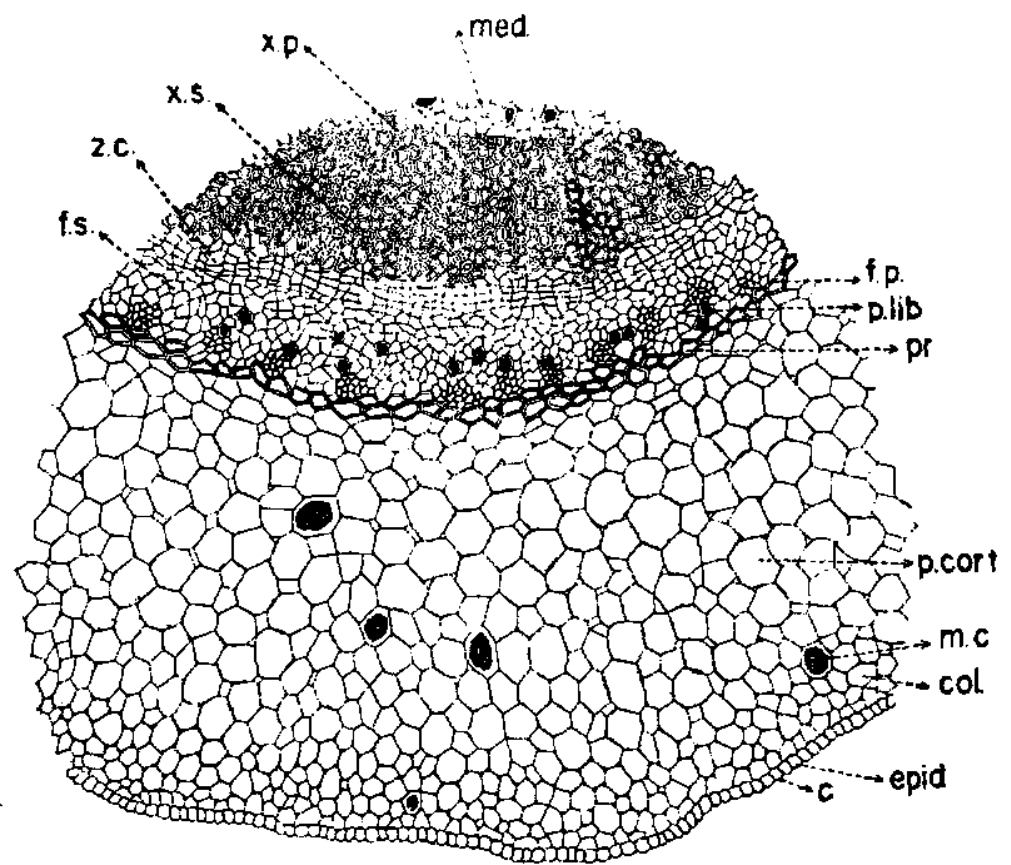

FIGURA 12 - Detalhes histológicos de um setor do corte da figura anterior $(60 \mathrm{X})$. aspecto estratificado; para o interior aparece o xilema secundário, cujos vasos ligulados, de placa perfurada simples e paredes laterais com potuações alternadas, são pequenos, medindo 700-900 micros de comprimento e 35-40 micros no seu diâmetro tangencial (fig. 13). Seguem-se o xilema primário e a medula.

O crescimento secundário do caule tem prosseguimento com o aparecimento do câmbio suberoso ou felógeno em uma região distante da gema apical. Cortes realizados aproximadamente a $4,5 \mathrm{~cm}$ da gema apical já evidenciam a existência de um periderma (pd), de espessura aproximada de 70 micros e que no seu contínuo desenvolvimento vai empurrando para o exterior os tecidos corticais e a epiderme (fig. 14). Êstes, incapazes de resistirem à pressão interna dos novos tecidos em formação, tornam-se comprimidos e esmagados e acabam por se dilacerar e desprender do caule.

O felógeno ou câmbio suberoso tem origem a partir do crescimento e de repetidas divisões tangenciais das células que constituem as camadas mais internas do parênquima cortical. As primeiras porções do câmbio suberoso que se formam desenvolvem-se e, em pouco tempo, constituem um cilindro contínuo e estreito de felógeno. A partir dêste câmbio suberoso, graças às repetidas 
divisões tangenciais das suas células resultam, para o exterior, camadas de súber, e para o interior, camadas parenquimatosas de feloderma. Observando-se um corte do caule neste estágio de desenvolvimento, nota-se que na sua estrutura estão presentes as regiões de tecidos (fig. 14) dadas a seguir.

Epiderme unisseriada, de células comprimidas e em vias de dilaceramento; colênquima e parênquima corticais completamente

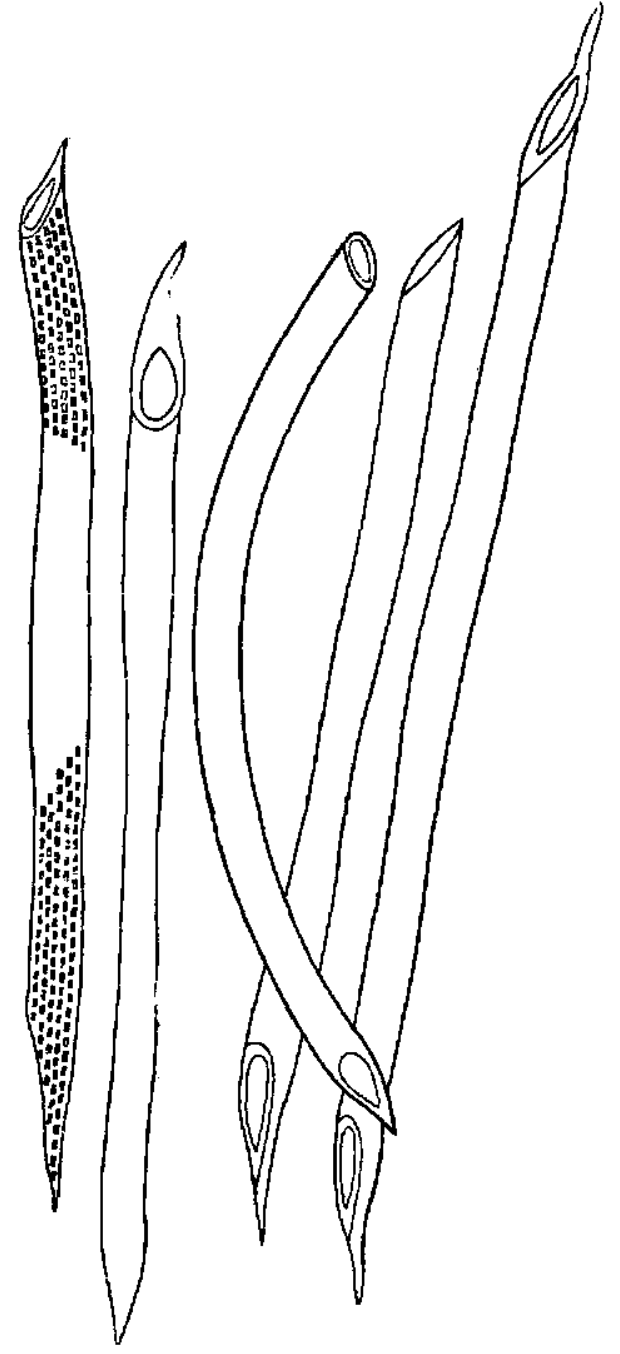

FIgURA 13. - Vasos ligulados do xilema secundário do caule, mostrando a placa perfurada simples $\mathrm{e}$ as paredes laterais com pontuações alternadas $(48 \mathrm{X})$. esmagados e distorcidos; periderma apresentando um aspecto estratificado e onde se notam os seguintes tecidos distintos pelas suas propriedades: uma ou duas camadas de súber ( $\mathrm{sb}$ ), constituídas de células grandes, compactamente unidas entre si, vazias e destituídas de protoplastos na maturação e providas de deposições de suberina nas suas paredes não pontuadas; felógeno (fe), representado por uma camada estreita de células vivas, de citoplasma denso e núcleo volumoso; feloderma (fel), representado por 2 a 3 camadas de células menos espêssas que as do súber, estratificadas, dotadas de protoplasto e de paredes celulósicas com pontuações. Em seguida ao periderma surge o periciclo, representado por duas camadas de fibras que exibem uma seção transversal poligonal, paredes secundárias bastante espêssas e luz ou lúmen das células muito reduzido. Seguem-se as porções de floema primário, representado por tubos crivosos grandes e de paredes esmagadas, células companheiras e parênquima liberiano; floema secundário, de elementos menores, não comprimidos; zona cambial, exibindo um aspecto estratificado; xilema secundário representad o por grandes vasos pontuados, traqueídes de espessamentos espiralados, e fibras lenhosas não septadas; mais no interior encontra-se o xilema primário, de igual constituição ao anterior, porém, as suas células exibem um espessamento secundário das paredes muito mais acentuado; finalmente, a região central está ocupada pela medula, formada de grandes células parenquimatosas. Por entre os feixes lenhosos e liberianos do xilema e floema secundário dispõem-se raios medulares uni- e bisseriados. 


\section{3 - FÔLHAS}

A. variedade typica de C. arabica apresenta fôlhas opostas, decussadas, dorsiventrais, curto-pecioladas, de lâmina elítica ou elítico-lanceolada, atenuada em ambas as extremidades, glabra, verde-luzidia na página superior e verde clara inferiormente, medindo 90-180 $\mathrm{mm}$ de comprimento e $30-70 \mathrm{~mm}$ de largura; nervação reticulada, nervura mediana desenvolvida, com 9-12 nervuras secundárias de ambos os lados, recurvadas, salientes na página inferior; bordas inteiras, levemente onduladas; estípulas interpeciolares, deltóides, agudas.

\subsection{1 - PECÍOLO}

Em cortes transversais praticados quase ao nível da inserção da fôlha sôbre os ramos, o pecíolo exibe um contôrno em forma de escudo, sendo provido na parte superior de duas azas ou aurículas que representam os primeiros estágios da expansão do limbo foliar (fig. 15). O seu sistema vascular está representado por um grande feixe central, em forma de arco fechado e que irá constituir a nervura mediana da fôlha. Êste grande feixe vascular central é acompanhado de dois feixes menores, na parte superior e ao nível das azas, e que igualmente exibem o xilema voltado para a epiderme superior e o floema dirigido para a epiderme inferior. $O$ sistema vascular do pecíolo, assim constituído, é enquadrado no tipo tricíclico. Completam o seu suprimento vascular, feixes menores que nas seções transversais aparecem por entre o tecido parenquimatoso

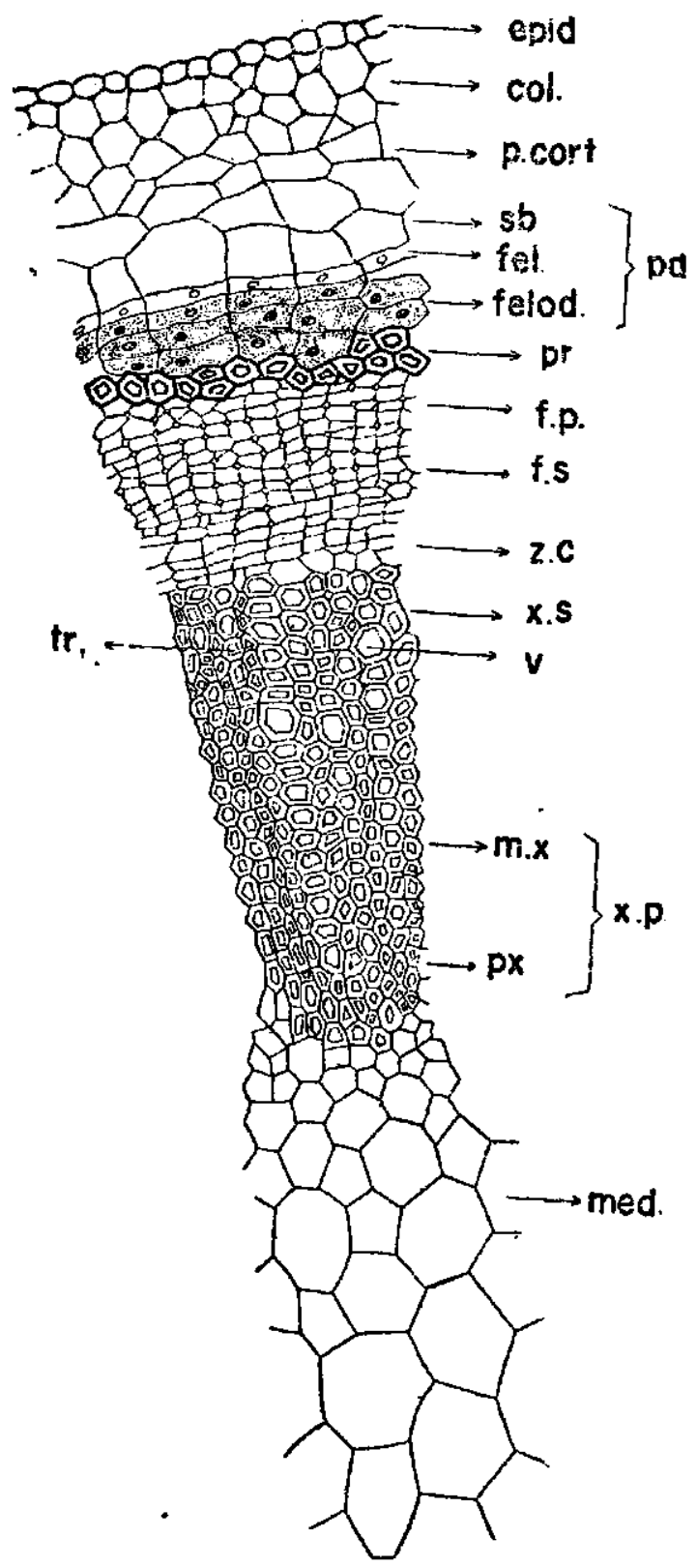

Figura 14. - Estrutura secundăria do caule: - corte transversal praticado cêrca de $4,5 \mathrm{~cm}$ da gema apical, com o periderma já visível (140 X). col. = colênquima; epid. $=$ epiderme; fel. = felogeno; felod. := feloderme; f.p. = floema primálio; f.s. = floema secundálio; med. = medula; $\boldsymbol{m x}=$ metaxilema; p.cort. $=$ parênquima cortical; pd $=$ neriderma; $\mathbf{p r}=$ periciclo; $\mathbf{p x}=$ protoxilema; $\mathbf{s b}=$ súber; tr $=$ traqueide; x.p. = xilema primário; x.s. = xilema secundário; z.c. $=$ zona cambial. 
cortical em direção às azas, e cujo tamanho diminui no sentido da periferia do corte. Esses feixes secundários (n.l.), que apresentam uma disposição normal dos tecidos vasculares, isto é, o xilema voltado para a epiderme superior e o floema para a epiderme inferior, representam ramificações do grande feixe central.

Histològicamente o pecíolo apresenta a seguinte constituição (figs. 15 e 16) : epiderme unisseriada, semelhante à do caule, com delgada cutícula; um colênquima angular sub-epidérmico representado por 2-3 camadas de células; parênquima cortical formado de células grandes, poligonais ou mesmo arredondadas, que aumentam da periferia para o centro e que deixam visiveis espaços triangulares entre si. Essas células são ainda caracterizadas pelas suas inclusões de amido e de oxalato de cálcio, as últimas sob a forma de volumosas massas de cristais granulares; Mariani (27) e Chevalier (7) assinalaram, igualmente, para estas células a ocorrência de material tanóide. A camada mais interna do córtex não exibe as características típicas de um endoderma, tal como já se verificara.

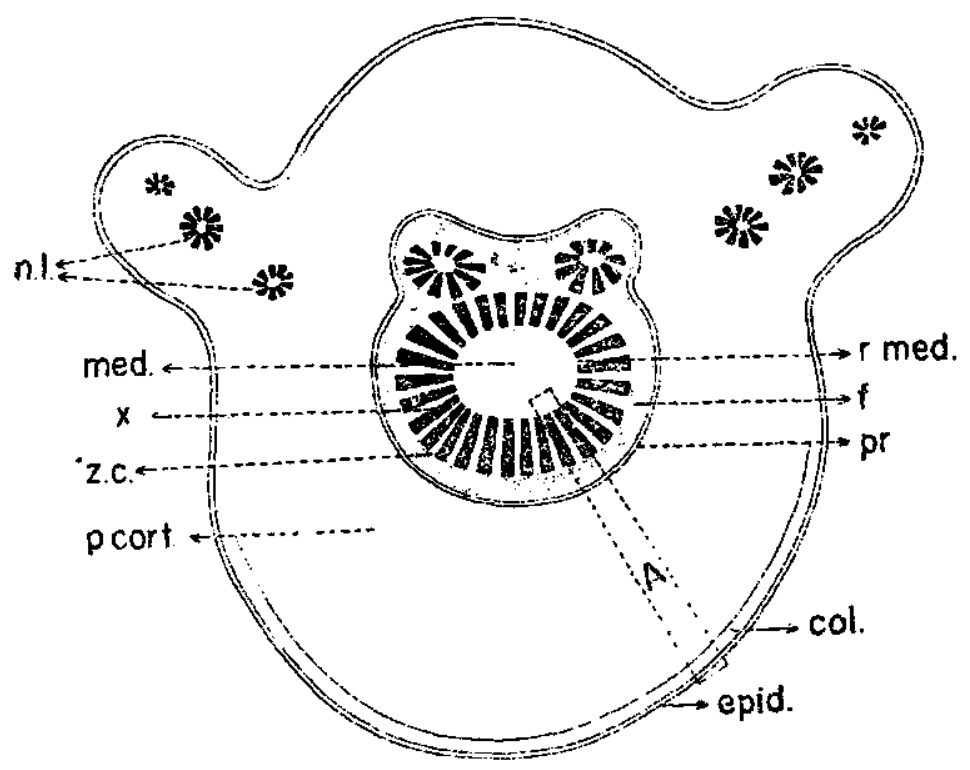

Frgura 15. - Desenho esquemático do peciolo segundo um corte transversal praticado na base do limbo foliar (26 X). col. = colênquima; epid. $=$ epiderme; $\mathbf{f}=$ floema; med. = medula; n.l. = feixes secundários (nervuras laterais); p.cort. $=$ parênquima cortical; $\mathbf{p r}=$ periciclo; r.med. $=$ raics medulares; $\mathbf{x}=$ xilema; $\mathbf{z . c .}=$ zona cambial.

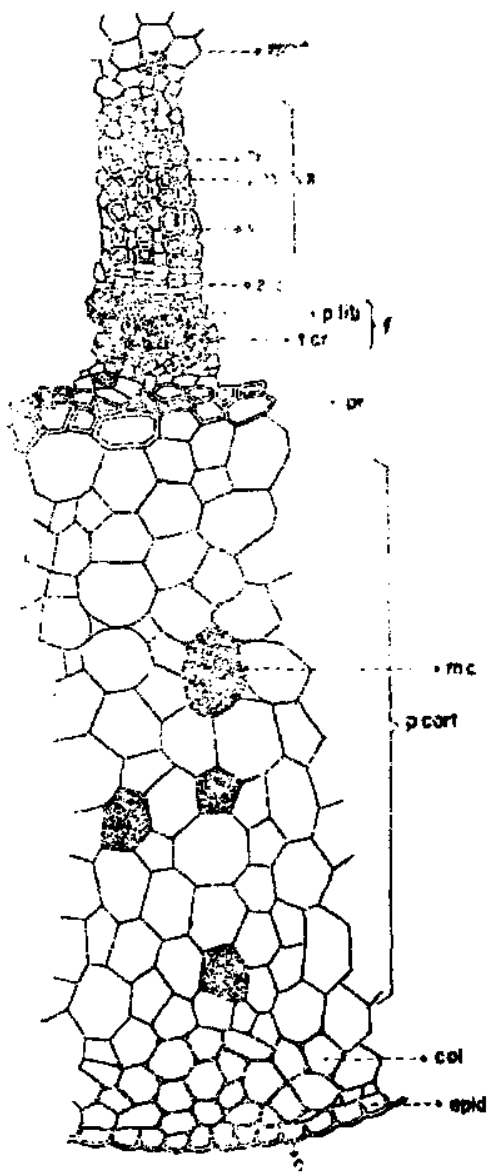

Figura 16. - Detalhes histológicos do setor $A$, assinalado na figura anterior $(80 \mathrm{X})$. c $=$ cuticula; col. $=$ colênquima; epid. = epiderme; $\mathbf{f}=$ floema; med. = medula; m.c. = massa de cristais; p.cort. $=$ parênquima cortical; p.lib. = parênquima liberiano; $\mathbf{p r}=$ periciclo; r.m. = raio medular; t.cr. = tubo crivoso; tr $=$ traqueíde; $\mathbf{x}=$ xilema; z.c. $=$ zona cambial. 
no caule. A presença de grãos de amido nas células que compõem essa camada tem sido o critério adotado por alguns autores para designá-la de endoderna. O periciclo constitui um anel quase contínuo ao redor do grande feixe vascular central e dos dois feixes menores e mantém-se no estado de células parenquimatosas ao longo de todo o pecíolo; raras vêzes algumas de suas células estão transformadas em fibras, a não ser na parte apical do pecíolo, já à altura da base do limbo, onde então as fibras são freqüentes. $O$ floema, representado por conjunto de tubos crivosos e células companheiras separados entre si por um parênquima liberiano abundante, forma um cilindro contínuo que rodeia todo o xilema; nas células do parênquima liberiano são freqüentes as inclusões de oxalato de cálcio. O xilema, que como foi dito se apresenta na forma de um cilindro contínuo, é formado por mais de 50 feixes dispostos radialmente e separados entre si por raios medulares uni- e bisseriados. Cada feixe é constituído de 6 a 7 elementos traqueais bem desenvolvidos. Por entre o floema e o xilema é visível a existência de uma zona cambial.

A região central do grande feixe vascular está ocupada por uma medula de células parenquimatosas arredondadas, que deixam grandes espaços poligonais entre si e que encerram grãos de amido, massas de cristais granulares de oxalato de cálcio e tanino.

\subsection{2 - LAMMINA FOLIAR}

Cortes transversais da lâmina foliar exibem uma estrutura normal, típica das fôlhas de simetria dorsiventral, como a seguir.

Epiderme superior ou adaxial, unisseriada, constituída exclusivamente de células epidérmicas de base poligonal (fig. 18), e que em vista superficial apresentam-se com contornos sinuosos. As células dessa epiderme, revestidas por uma delgada cutícula, são relativamente grandes na região do limbo foliar e tornam-se bem menores na epiderme que reveste o feixe vascular central correspondente à nervura mediana. A parede tangencial externa dessas células é a mais espêssa; as laterais ou radiais apresentam-se retilíneas, pontuadas, são mais delgadas, a sua espessura diminuindo para o interior.

Epiderme inferior ou abaxial, também unisseriadà, mas que difere em vários respeitos da superior. Constitui-se ela de células epidérmicas menores que as da epiderme superior, seja na região do limbo, seja na região da nervura mediana. Ȧs células epidérmicas juntam-se os estomas que são em grande número e que exibem uma estrutura tìpicamente rubiácea já descrita por Solereder (35) e minuciosamente estudada por Accorsi $(1,2,3)$. As células estomáticas fazem-se acompanhar de duas células anexas (c.a.) e os estomas assim constituídos estão situados no mesmo nível das 
células epidérmicas (figs. 19 e 20). Franco (14), estudando a relação entre o número de estomas e o de cromossomos das diferentes espécies de cafeeiros, verificou que o primeiro diminui à medida que o último cresce, isto é, nas formas triplóides e tetraplóides é menor o número de estomas por unidade de área, do que nas formas diplóides. Para a variedade typica, que é um cafeeiro tetraplóide, numa contagem realizada em 24 espécimes, encontrou o autor citado o valor aproximado de 160 estomas por milímetro quadrado. De Wildeman (39) realizou pesquisas semelhantes e os seus resultados confirmam parcialmente o que foi atrás exposto.

Digna de especial menção é a ocorrência, na epiderme inferior, de poros ou aberturas de certas estruturas denominadas domácias, cujo estudo detalhado será feito mais adiante.

Mesofilo foliar - na região do limbo o mesofilo foliar apresenta-se constituído por uma só camada de parênquima paliçádico (p.p.), localizado logo abaixo da epiderme superior, e formado de células compactamente unidas entre si e dispostas com o seu maior eixo perpendicularmente à epiderme, ricas em cloroplastos e grãos de amido, representando aproximadamente $1 / 5$ a $1 / 6$ da espessura de todo o mesofilo foliar (fig. 17). Em sucessão ao parênquima paliçádico aparece o parênquima esponjoso ou lacunoso (p.s.), que constituindo a maior parte do mesofilo foliar mostra ser formado por 10-12 camadas de células que se dispõem de maneira irregular,

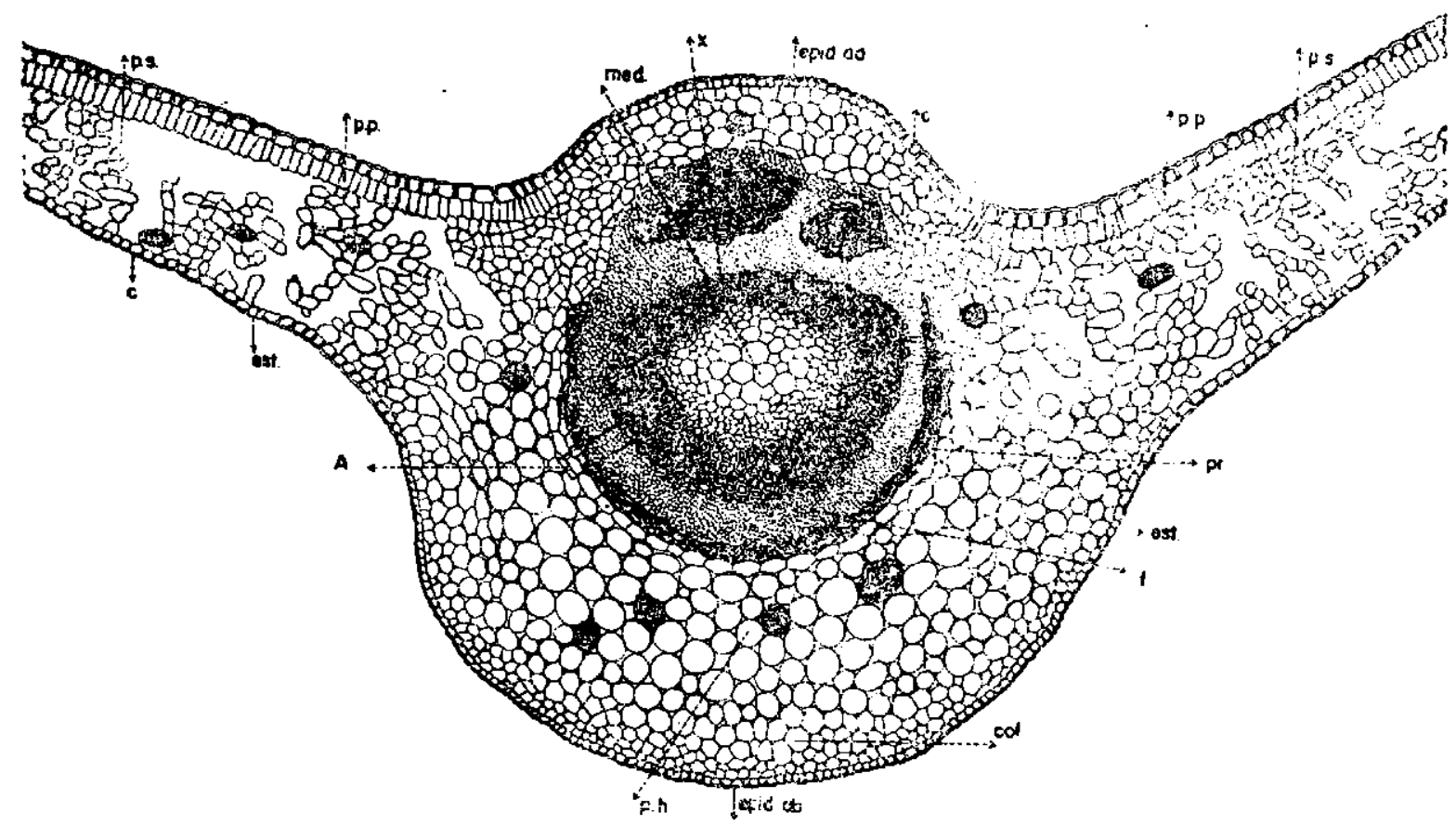

Frgura 17. - Corte transversal da lâmina foliar $(35 \mathrm{x}) . \mathrm{c}=$ cutícula; col. = colênquima; epid.ab. = epiderme abaxial; epid.ad. = epiderme adaxial; est. $=$ estoma; $\mathbf{f}=$ floema; med. = medula; p.h. = parênquima hialino; p.p. $=$ parênquima paliçádico; $\mathbf{p r}=$ periciclo; p.s. $=$ parênquima esponjoso; $\mathbf{x}=$ xilema. 


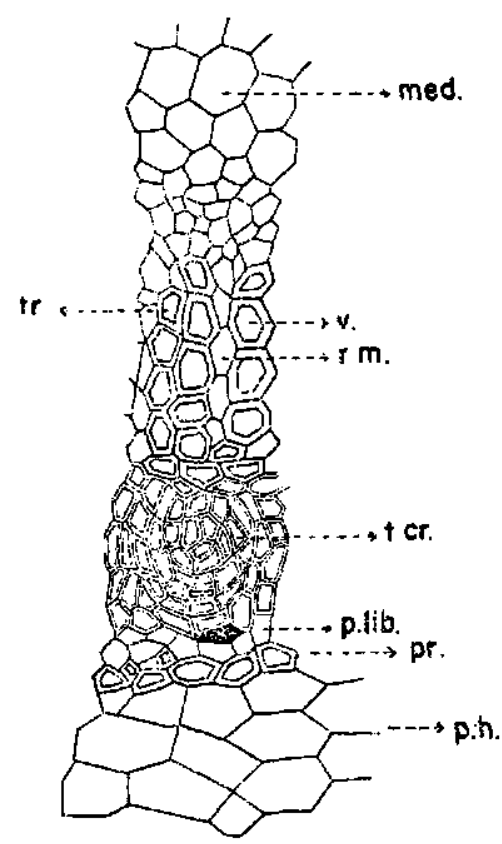

Figura 18. - Detalhes histológicos do setor $A$, assinalado na figura anterior $(175 \mathrm{X})$. med. = medula; p.h. = parênquima hialino; p.lib. = parênquima liberiano; pr $=$ periciclo; r.m. $=$ raio medular; t.cr. $=$ tubo crivoso; $t r=$ traqueíde; $\mathbf{v}=$ vaso.

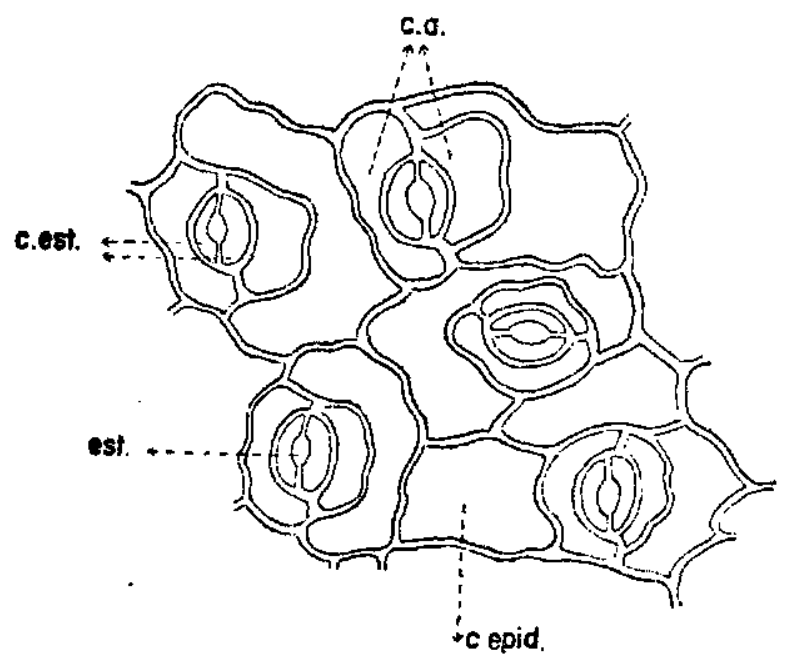

Figura 19. - Vista superficial dos estomas da epiderme abaxial ou inferior da fólha, exibindo a sua estrutura tipicamente rubiácea $(285 \mathrm{X})$. c.a. $=$ células anexas; c.est. = células estomáticas; c.epid. = células epidérmicas; est. = estoma. menos ricas em cloroplastos e que deixam enormes espaços vazios entre si. Mergulhados no parênquima esponjoso e logo abaixo do parênquima paliçádico dispõemse os feixes vasculares correspondentes às nervuras secundárias e que nas seções transversais se apresentam gradativamente menores, à medida que se aproximam das bordas das fôlhas.

Grãos de amido e inclusões de oxalato de cálcio acham-se comumente presentes nas células do mesofilo foliar, o último sob a forma de massas compactas de pequenos cristais granulares e, segundo os estudos de Mariani (27), também o tanino ocorre nas células, quer do parênquima paliçádico, quer do esponjoso. A reação de tanino foi pesquisada pelo autor em questão, em cortes de material vivo, concluindo o mesmo que os compostos de tanino nas fôlhas do cafeeiro estão ligados à cafeina, embora êsse complexo químico não tenha sido ainda isolado das fôlhas.

Nas formas variegadas de cafeeiro da mesma variedade, segundo Dedecca (8) a variegação parece ser devida a certas anormalidades na constituição dos cloroplastos ou distúrbios no mecanismo da formação da clorofila, resultando disto a ocorrência de células contendo cloroplastos normais (verdes, grandes e numerosos), ao lado de células que encerram cloroplastos anormais (amarelados, pequenos e reduzidos em número).

$\mathrm{Na}$ região da nervura mediana modifica-se a organização do mesofilo foliar, que se apresenta então constituído por um parênquima de células arredondadas, na forma de 7-8 camadas de células hialinas, dispostas de uma maneira concêntrica ao redor do grande feixe vascular mediano. 
As células dêste parênquima hialino (p.h.) são sempre pobres em cloroplastos, deixam grandes espaços vazios entre si e encerram com frequiência as inclusões de oxalato de cálcio e de material tanóide já assinaladas. As camadas mais exteriores dêste parênquima, próximas à epiderme inferior da fôlha, estão diferençadas em um colênquima angular (3-4 camadas) que é a continuação do colènquima sub-epidérmico do pecíolo.

Sistema vascular - está representado na parte central por um grande feixe vascular, correspondente à nervura mediana, e dois feixes menores (estrutura tricíclica). Em ambos os lados, nas metades do limbo foliar, aparecem feixes menores que representam as nervuras laterais, que se ramificam várias vêzes, dando ensejo a que se forme um sistema de nervuras reticulado. Nos cortes praticados na base do limbo foliar, êsses feixes vasculares secundários apresentam o xilema voltado para a epiderme superior e o floema dirigido para a epiderme inferior, envolvidos por um anel de células parenquimatosas.

O floema constituise de massas de tubos crivosos, células compa-

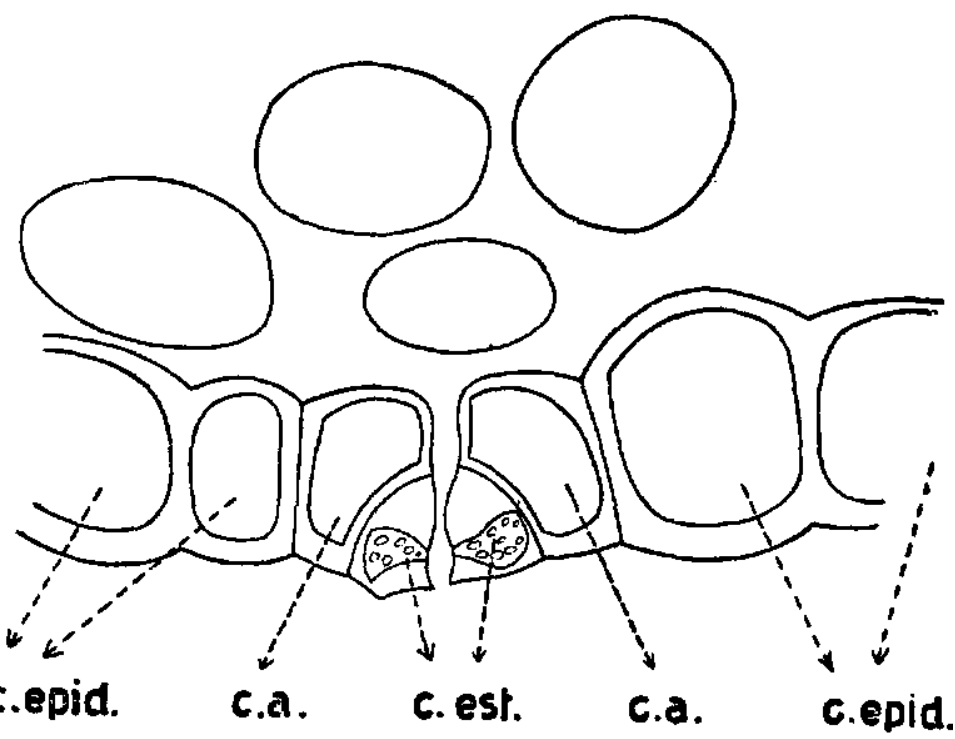

Figura 20 - Estoma segundo um corte transversal do limbo foliar $(770 \mathrm{X})$. c.a. = células anexas; c.epid. = células epidérmicas; c.est. = células estomáticas.

nheiras e fibras liberianas, imersas no parênquima liberiano (fig. 18). Os elementos traqueais do xilema dispõem-se em 50-60 séries radiais; estas séries são constituídas de 4-8 elementos bem desenvolvidos e acham-se separadas entre si por raios medulares uni- e bisseriados. No interior do xilema está a medula formada de tecido parenquimatoso, cujas células encerram grãos de amido, inclusóes de oxalato de cálcio e material tanóide.

O endoderma não é distinto; ao contrário, o periciclo apresenta-se sob a forma de um anel esclerenquimatoso contínuo, com a espessura de 2-3 células, a maioria das suas células sob a forma de fibras de paredes espêssas.

\subsection{3 - DOMÁCIAS}

Um dos traços mais característicos da fôlha do cafeeiro é a ocorrência de certas estruturas, chamadas domácias ou ácaro-domácias (fig. 21 e est. $1-C$ ), que na maioria dos casos se localizam no 
ângulo formado pela nervura principal com as nervuras secundárias e se abrem na epiderme inferior sob a forma de poros visíveis mesmo a ôlho nu. Estas estruturas têm sido objeto de estudo de vários investigadores, inclusive Mariani (27), que verificou a constante ocorrência das mesmas em 51 espécies e 5 variedades de cafeeiros.

A palavra domácia (domatia $=$ pequena casa ou pequeno abrigo) segundo Jackson (22), parece ter sido criada por Tubeuf, para indicar pequenas projeçôes ou saliências nos tecidos dos diversos órgãos das plantas e que têm por finalidade abrigar determinados parasitos. Embora já em 1864 Marchand tivesse assinalado a presença de domácias em $C$. arabica L., só bem posteriormente a sua ocorrência foi verificada em outras espécies do gênero Coffea e de

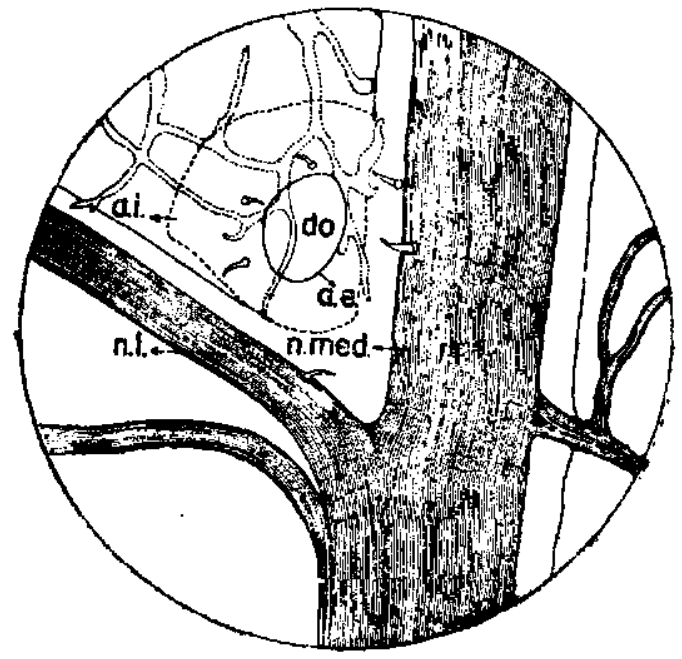

Figura 21. - Vista superficial da epiderme abaxial da fôlha, exibindo uma domácia na axila da nervura mediana com uma nervura lateral (35 X). a.i. = abertura interna; a.e. $=$ abertura externa; do $=$ domácia; n.I. = nervura lateral; n.med. = nervura mediana. outros gêneros mais ou menos afins da família Rubiaceae. Daí por diante têm sido as domácias objeto de muitos estudos por vários pesquisadores que lhes têm, através dos tempos, atribuído um maior ou menor significado sistemático e fisiológico. De Willdeman (39) e Mariani (27) estão entre êstes pesquisadores e nos seus trabalhos pode ser encontrada uma revisão bem completa do assunto.

A domácia (do) apresenta-se como uma pequena cripta ou cavidade que se aprofunda pelo parênquima esponjoso a dentro; esta cripta ou cavidade em forma de saco, abre-se exteriormente, na epiderme inferior da fôlha, por um poro arredondado, oval ou elítico, de diâmetro variável e cujas bordas podem se apresentar glabras ou revestidas por uma pilosidade mais ou menos abundante; a cavidade dilata-se para o interior do mesofilo foliar e na sua parte mais interna atinge um diâmetro 2 a 3 vêzes maior que o da abertura exterior (fig. $21 \mathrm{e}$ est. 1-D). A presença da domácia não é, contudo, visível na fôlha antes que esta atinja um certo desenvolvimento, já que ela não é aparente nas fôlhas ainda muito novas. A sua observação, a ôlho nu, é possivel sòmente quando a fôlha possui um comprimento de $3,5 \mathrm{~cm}$, o que equivale aproximadamente a um período de 75-80 dias na vida da fôlha (fig. 22). Ainda mais, a sua presença é inicialmente constatada apenas nas axilas das nervuras inferiores 


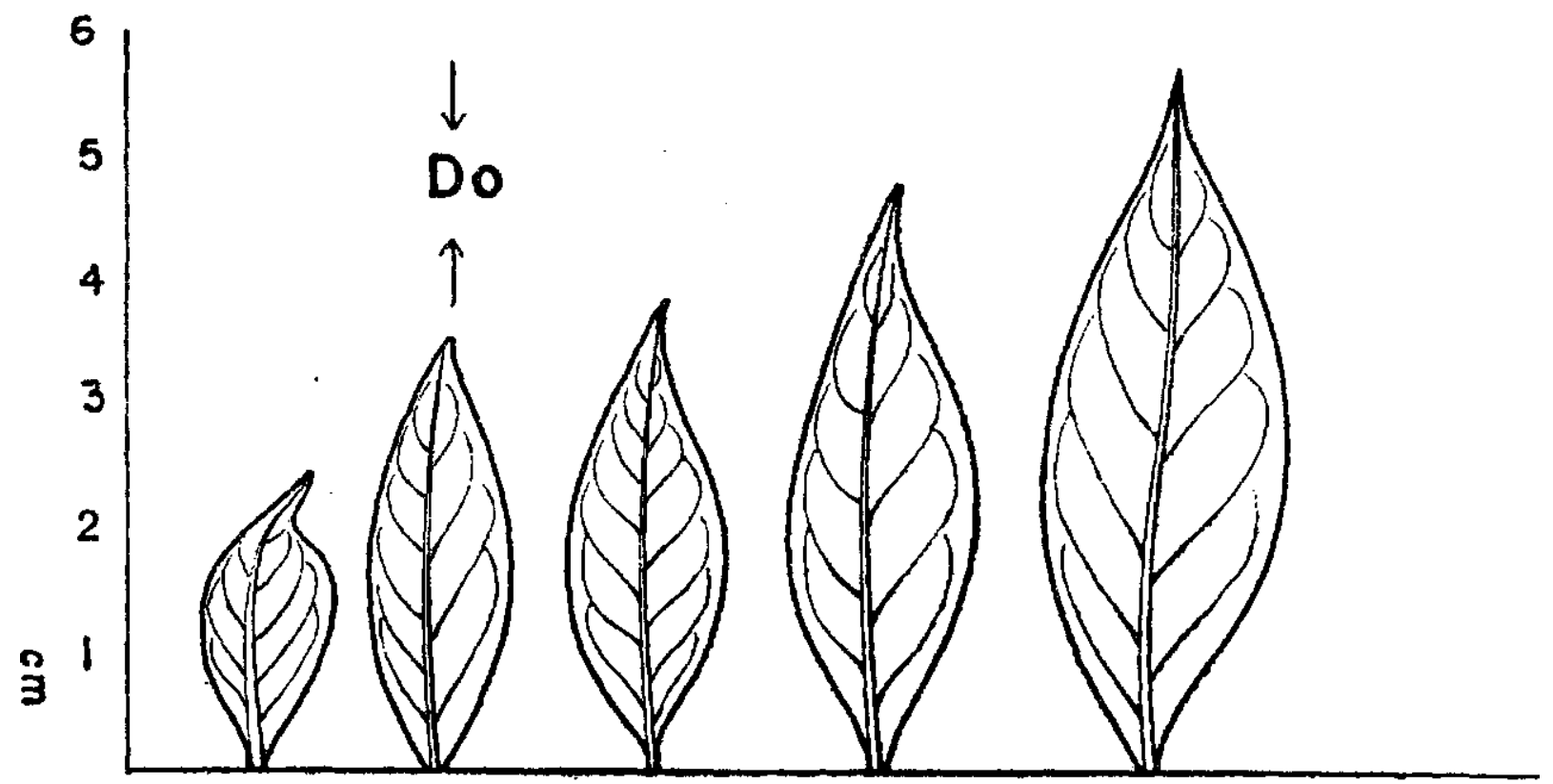

Figura 22. - Gráfico indicando a relação entre o desenvolvimento das fôlhas e o tempo em que as domácias se tornam visíveis mesmo a ôlho nu.

da fôlha, e o primeiro indício do seu aparecimento é representado por um tufo de longos pêlos (fig. 23). O estudo de cortes transversais da fôlha na região das domácias revela a sua forma vesicular (fig. 24, $A-F$ ). O aparecimento de uma domácia é revelado pela formação de um aglomerado de células no parênquima esponjoso, que diferem das células vizinhas pelo seu aspecto irregular, devido aos diferentes planos de divisão celular. A seguir surge uma cavidade na parte central dêsse massiço irregular de células, ao mesmo tempo que estas células vão assumindo uma disposição estratificada. A cavidade cresce progressivamente no sentido centrífugo até atingir a epiderme inferior, que parece se invaginar e revestir a cavidade exteriormente. A cripta assim formada expande-se ao máximo e a seguir começa a se fechar gradativamente, repetindo tôdas as fases que antecederam à sua abertura para o exterior, para finalmente desaparecer num aglomerado irregular de células. A camada de células que reveste a cavidade tem sempre aspecto de epiderme e nela podem ser encontrados estomas. A sua profundidade no mesofilo é, segundo Mariani (27), muito variável nas diferentes espécies e variedades de cafeeiro, assinalando

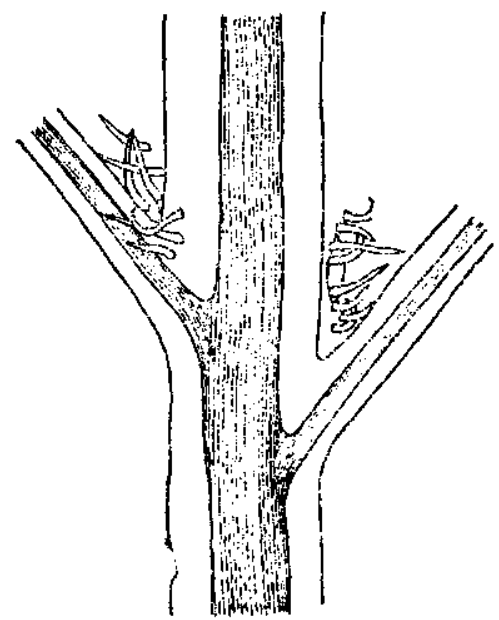

Figura 23. - Vista superficial da epiderme inferior de uma fôlha rova, evidenciando o tufo de pêlos que assinala o aparecimento de uma domácia $(50 \mathrm{X})$. 
o mesmo autor que em Coffea arnoldiana De Wild. e C. alleizetti Dub., por exemplo, a grande profundidade da domácia chega a determinar uma pequena saliência na página superior da fôlha. Em Coffea arabica L. var. typica Cramer as domácias, de um modo geral, aprofundam-se no mesofilo foliar um pouco além da sua parte mediana, não chegando, contudo, a atingir o parênquima paliçádico.
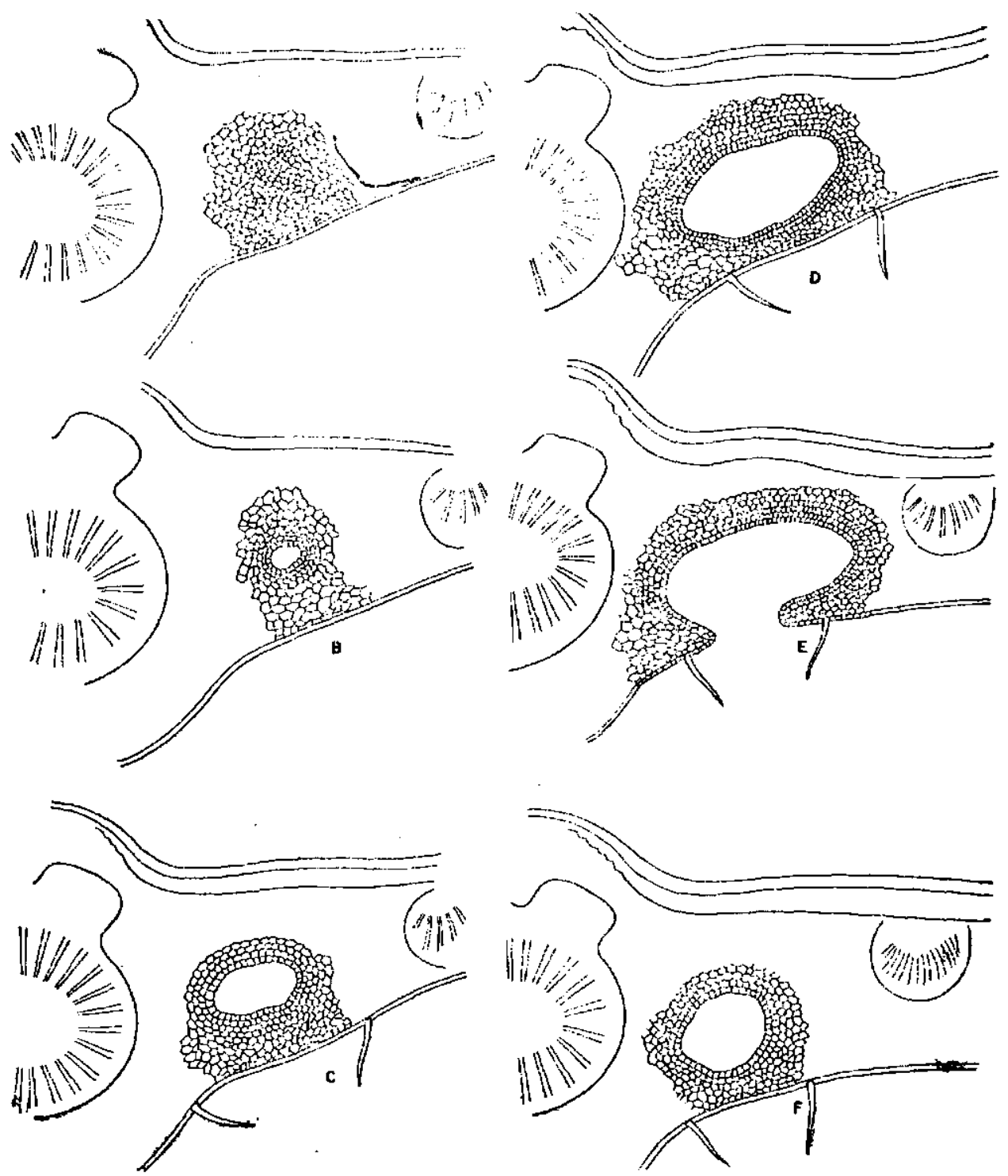

Figdra $24-A-F-$ Seis estágios sucessivos de uma domácia, segundo cortes transversais, mostrando a sua forma vesicular $(60 \mathrm{X})$.

Uma vez verificada a constância da ocorrência das domácias nas fôlhas de determinadas rubiáceas, duas questões principais foram a seguir o objeto de minuciosos estudos: o seu significado fisiológico e a sua morfologia. Do ponto de vista fisiológico, desde o início admitiu-se serem as domácias o abrigo, refúgio ou domi- 
maior porção (fig. 25) ; estruturalmente muito se assemelham às fôlhas. Por entre as epidermes superior e inferior, de células grandes, localiza-se um mesofilo homogêneo constituído de 3-4 camadas de células parenquimatosas alongadas, ricas em cloroplastos e com grandes espaços intercelulares, no seio das quais está distribuído o sistema vascular representado por um feixe central maior, em cujos lados aparecem 3-4 feixes gradativamente menores à medida que se aproximam das bordas da estípula.

\section{4 - FLôRES}

As flôres do cafeeiro dispõem-se em glomérulos axilares, em número variável de 2-19 por axila, envolvidas por um calículo formado por dois pares de bractéolas, respectivamente lanceoladas e triangulares.

\section{1 - INFLORESCENCIA $\mathrm{E}$ GEMAS FLORAIS}

O estudo da composição da inflorescência de Coffea e do desenvolvimento ontogenético das gemas florais (est. 2 - $A-I$ ) foi detalhadamente realizado por Der Meulen (9).

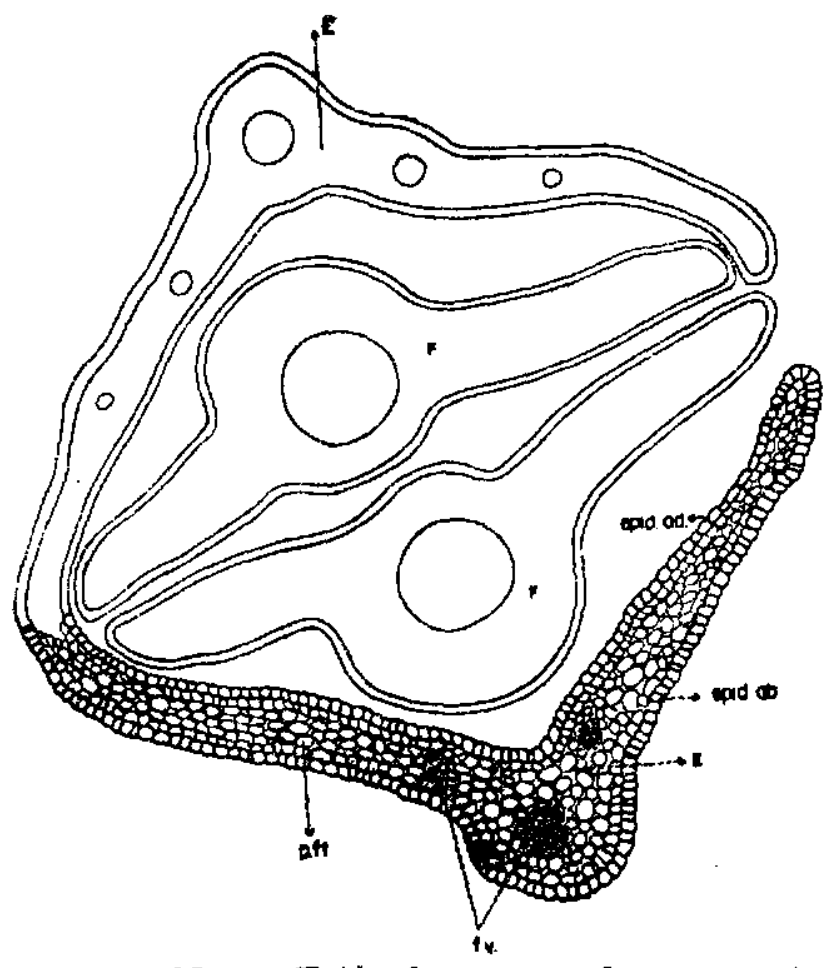

Figura 25. - Estípulas, segundo um corte transversal $(60 \mathrm{X}) . \mathbf{E}=$ estípulas; epid.ab. = epiderme abaxial; epid.ad. $=$ epiderme adaxial; p.ft. = parênquima fotossintético; f.v. = feixe vascular.

Êste estudo revelou que a inflorescência é do tipo homotático composto, ou seja, uma inflorescência na qual os eixos laterais têm - mesmo sistema de formação que o eixo principal. Pode mesmo ser dito que a inflorescência de Coffea arabica L. é, em princípio, a continuação da estrutura da porção vegetativa, as brácteas e bractéolas nesta inflorescência sendo homólogas às verdadeiras fôlhas e às estípulas interpeciolares dos ramos vegetativos de primeira e segunda ordem.

Os eixos laterais da inflorescência nascem a partir de gemas dispostas em séries descendentes, nas axilas formadas pelos pares cruzados de fôlhas com os ramos primários. Cada gema desta série desenvolve-se em um eixo curto, que termina numa flor. Nestes novos eixos nascem pares de brácteas, também cruzados, na axila das quais se formam outras séries descendentes de gemas. Por sua vez, essas gemas dão origem a novos eixos curtos, semelhantes aos eixos-mãe etc., e o processo se repete por diversas vêzes. 
Como os eixos que suportam as flôres são sempre muito curtos, a inflorescência em conjunto assume um aspecto compacto, o que the valeu a denominação de glomérulo, dada por diversos autores. $\mathrm{O}$ desenvolvimento das gemas parece obedecer às regras seguintes:

a) dentro da mesma série de gemas o desenvolvimento se processa a partir da gema que se encontra mais próxima ao seu eixo floral;

b) as gemas pertencentes a uma ramificação de ordem superior desenvolvem-se primeiro que aquelas das ramificações de ordem inferior;

c) dentre as gemas das ramificações de mesma ordem, o desenvolvimento se dá em primeiro lugar nas das axilas superiores, e prossegue no sentido daquelas situadas nas axilas mais inferiores.

As investigações de Der Meulen (9) ainda revelam que os primórdios florais aparecem na axila formada pelas brácteas com 0 eixo da inflorescência, sob a forma de estreitas faixas de tecido meristemático, que logo entram em diferençação. No interior das brácteas são encontrados numerosos pêlos glandulares que segregam uma substância cerosa. As bordas superiores de cada primórdio desenvolvem-se formando pequenas saliências que conferem a cada primórdio uma forma angulosa (est. $2-C$ ) ; os vértices ou ângulos são o início da diferençação das sépalas (S), que permanecem sempre pequenas. Simultâneamente com a aquisição da forma anguìsa, a face superior do primórdio floral achata-se e o cálice em formação torna-se visível sob a forma de pequenas elevações. A porção periférica do primórdio, que se situa acima e dentro das saliências que representam as sépalas, desenvolve-se para cima, a sua parte central permanecendo em situação inferior. Sôbre as paredes do anel que assim se desenvolve aparecem os primórdios das pétalas (P) em situação alternada à das sépalas (est. $2-D$ ). Os estames (stm) são os próximos órgãos a se diferençarem e o seu aparecimento se dá sob a forma de pequenas projeçôes no interior do anel formado pelas pétalas e em posição alternada aos primórdios destas. A flor em formação assume gradativamente um aspecto contorcido. Para o reconhecimento das demais fases que marcam a diferençação dos carpelos (cr) torna-se necessária a remoção dos estames e das pétalas do primórdio floral em estudo. As modificações que assinalam o aparecimento dos carpelos são as seguintes (est. $2-E-I$ ) : o receptáculo floral alarga-se, as suas bordas tornam-se erguidas constituindo um anel espêsso no centro do qual permanece imersa a parte central do primórdio floral, que desde o início ocupava uma posição inferior. Dois pontos opostos nos bordos do espêsso anel formado pelo receptáculo tornam-se alargados e elevados e continuam a crescer um em direção ao outro. Estes dois novos desenvolvimentos representam os primórdios dos 
carpelos que logo a seguir passam a se desenvolver ligados entre si e constituem uma estrutura em forma de pequena elevação que apresenta uma pequena fenda no centro. Os primórdios dos car-

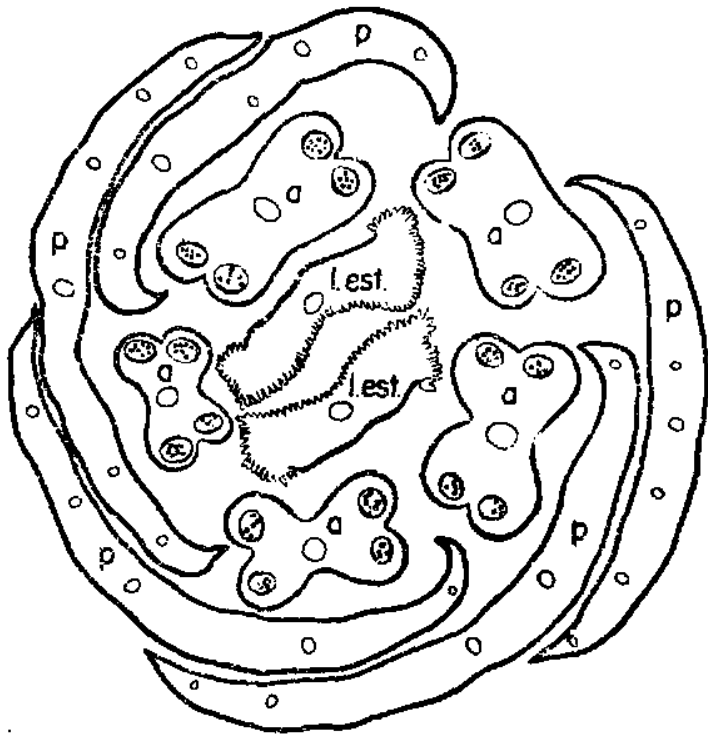

Figura 26. - Corte transversal no ápice de um botão floral, indicando a disposição e a composição dos diversos verticilos $(22 \mathrm{X}) . \quad \mathbf{P}=$ pétala; $\mathbf{a}=$ antera; l.est. $=$ logo estigmático. pelos desenvolvem-se ascendentemente para constituir o estilo e os lóbos estigmáticos; ao mesmo tempo a sua base se torna aplainada sob a forma de um disco pentagonal. Dêste modo tem formação o disco (d), colocado no interior do tubo da corola.

Cortes transversais praticados em botões florais põem em evidência a disposição dos diversos verticilos tal como o estudo ontogenético demonstrou. Os cortes realizados na parte superior do botão floral, atingindo o limbo da corola (fig. 26), mostram as cinco pétalas $(P)$, em situação mais exterior e que exibem uma disposição contorcida. Interiormente aparecem as cinco anteras (a), que se dispõem alternadamente às pétalas, e a região central é ocupada pelos dois lóbos estigmáticos (1.est.), aderentes pelas suas epidermes internas, papilosas. Se os cortes estudados forem praticados na base do tubo da corola (fig. 27), será possível perceber as sépalas (S), que poderão se mostrar livres (segmentos calicinos) où unidas formando o tubo do cálice, aderente ao ovário. Internamente às sépalas situa-se um anel contínuo que representa o tubo da corola, e no seu interior outra estrutura em forma de anel espêsso, que é o disco (d). Finalmente, na região central aparece o estilo que exibe uma seção circular (st).

\section{2 - ÓRGãos DE PROTEÇAO: \\ CALICE, BRACEAS E COROLA}

$O$ cálice da flor do cafeeiro apresenta-se rudimentar e constituído de cinco pequenos segmentos, persistentes no fruto. Estruturalmente cada sépala ou segmento é

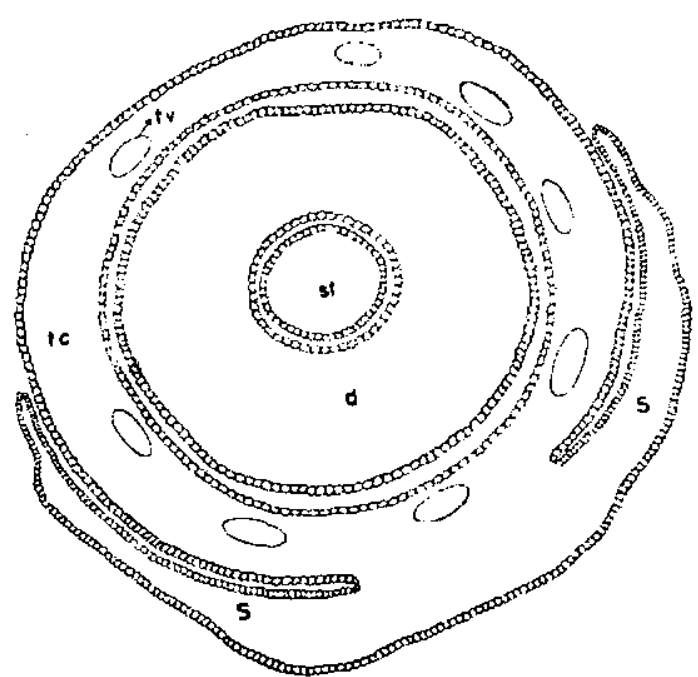

Figura 27. - Corte transversal de um botão floral, praticado na base da corola, mostrando o cálice rudimentar (S), o tubo da corola (t.c.), o disco (d) e o estilo (st) (30 X). 
uma fôlha modificada, exibindo uma estrutura muito semelhante à das estipulas. $O$ suprimento vascular das sépalas (t.v.) é representado por um traço único (fig. 28). O mesmo pode ser dito em relação às brácteas.

A corola é de côr branca, hipocraterimorfa, constituída de cinco pétalas unidas entre si até quase a parte mediana, formando um tubo, e o restante expandindo-se em um limbo formado por cinco segmentos lineares e obtusos. A estrutura da pétala, que é igualmente uma fôlha modifica-

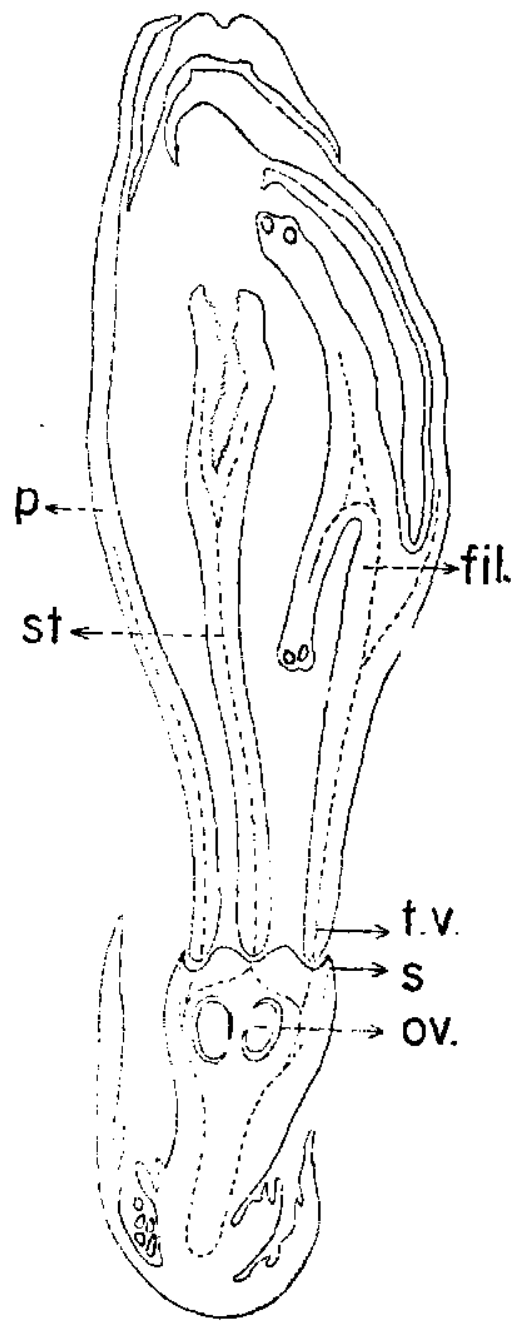

FIgura 28. - Corte longitudinal de um botão flo$r a l$, indicando os traços vasculares dos diversos elementos florais (21 X). fil. $=$ filete; ov. $=$ óvuIo; $\mathbf{P}=$ pétala; $\mathbf{S}=$ sépala; st $=$ estilo; t.v. $=$ traço vascular. da, apresenta-se diferente conforme a região considerada. Cortes transversais realizados no tubo da corola evidenciam que a pétala é constituída de epidermes, superior e inferior, por entre as quais se coloca um tecido parenquimatoso homogêneo, cujas células deixam pequenos espaços entre si. Na porção livre, ou seja na região do limbo, cada pétala exibe por entre as epidermes um parênquima esponjoso formado por 7-8 camadas de células (fig. 29), que são arredondadas ou oblongas e se dispõem de um modo irregular, sendo muito desenvolvidos os espaços vazios entre as células.

$\mathrm{Na}$ constituição da epiderme, além das células epidérmicas pròpriamente ditas podem ser encontrados estomas. Cada pétala apresenta um só traço vascular que se ramifica mais ou menos abundantemente, de modo a conferir à pétala uma nervação típica.

\section{3 - ÓRGÃOS DA REPRODUÇAO: ANDROCEU E GINECEU}

Os estames, em número de cinco, são epipétalos e inserem-se sôbre o tubo da corola em posição alternada às pétalas. Cada estame é constituído de um filamento 
cilíndrico, curto, de comprimento igual à têrça parte do comprimento da antera. O suprimento vascular do estame é também um só traço vascular, que se estende do filamento até a antera, através đo conetivo $(\mathrm{cn})$. O filamento, além do feixe vascular central e da epiderme unisseriada, exibe um parênquima homogêneo, normal. A antera no estado de maturação mede usualmente $8 \mathrm{~mm}(5-10 \mathrm{~mm})$, prende-se ao filamento por meio de um conetivo situado na sua porção dorsal e mediana, é bilocular ou bitécica, e exibe em corte transversal quatro sacos polínicos. O estudo da antera ainda verde, segundo cortes transversais, revela as seguintes zonas de tecidos (fig. 30) : epiderme unisseriada constituída de células grandes nos lados maiores da antera e paralelos às pétalas, células essas que diminuem gradativamente de tamanho no sentido dos lados menores; um tecido parenquimatoso de células grandes e encerrando freqüentemente uma substância de natureza provàvelmente tanóide, que assume uma côr escura nos cortes preparados permanentemente com os reativos já citados. $\mathrm{Na}$ região central, envolvido por êste tecido parenquimatoso, aparece o feixe vascular que veio indiviso desde o filamento. Cada saco polínico (s.p.) apresenta-se revestido exteriormente pela epiderme e mais 2-3 camadas de tecido parenquimatoso de células pequenas e dispostas de uma maneira concêntrica; internamente,

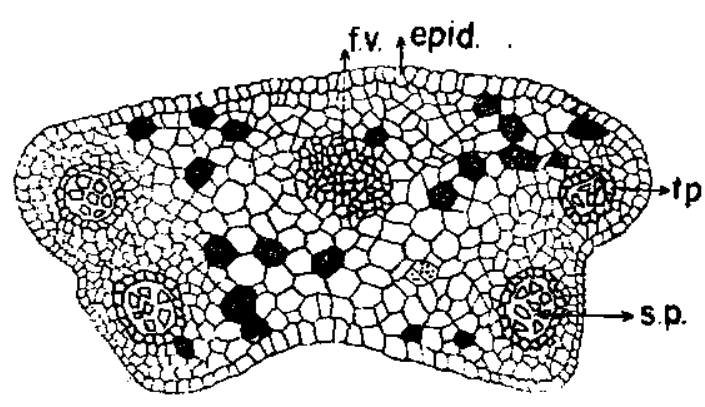

Figura 30. - Corte transversal de uma antera jovem $(96 \mathrm{X})$. epid. $=$ epiderme; f.v. $=$ feixe vascular; s.p. - saco polínico; $\mathbf{t p}=$ tapête. revestindo o saco polínico, está o tapête (tp), representado por uma só camada de células, e no seu interior localiza-se uma massa de tecido esporogênico. A microsporogênese de $C$. arabica L., investigada por Mendes (29), é perfeitamente normal.

Estudada quando no estado de maturação dos grãos de pólen, pouco antes da deiscência, a antera revela algumas das transformações que sofreu no seu amadurecimento (fig. 31). O feixe vascular central apresenta-se mais desenvolvido, e o parênquima que o rodeia mostra-se formado de células cujas paredes estão mais espêssas. $O$ tapête pràticamente desapareceu ou dêle sòmente restam vestígios. Ao redor de cada saco polínico aparece uma zona esclerenquimatosa representada por 2-3 camadas de fibras ( $\mathrm{fb}$ ), de disposição irregular e que serão diretamente responsáveis pela deiscência da antera segundo fendas longitudinais. No interior dos sacos polínicos estão os grãos de pólen (g.p.), que são numerosos, esféricos, de diâmetro variável entre 17 e 22 micros, de exina espêssa, 3-4 sulcada e apresentando poros circulares.

O gineceu está representado por um ovário ínfero, constituído de dois carpelos unidos; o estilo é terminal e assenta-se sôbre um 


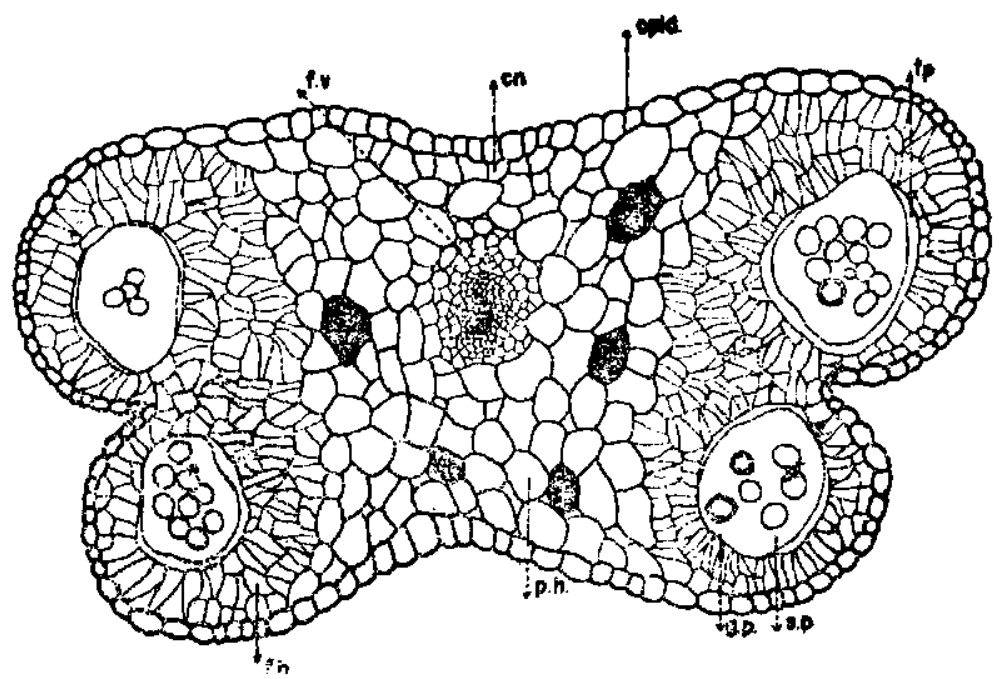

Figura 31. - Corte transversal de uma antera madura, pouco antes da sua deiscência $(90 \mathrm{X})$. cn $=$ conetivo; epid. = epiderme; fb $=$ fibras; f.v. $=$ feixe vascular; g.p. = grãos de pólen; p.h. = parênquima hialino; s.p. $=$ saco polínico; tp $=$ tapête.

disco carnoso nectarífero (d), e superiormente se bifurca em dois 'lóbos estigmáticos. 0 néctar segregado acumula-se na base do tubo da corola e segundo as observações de Santos (34), apresenta uma concentração de açúcar variável de 32 a $40 \%$.

O ovário é normalmente bilocular (fig. 32), cada lóculo encerrando um óvulo anátropo (ov), de funiculo curto e inserido em placentas centrais. A epiderme externa do ovário é representada por uma camada de células estreitas e a ela se segue uma extensa região parenquimatosa (futuro mesocarpo do fruto), onde se dispõem 2-3 séries concêntricas de feixes vasculares. Grande número de células parenquimatosas exibe um conteúdo escuro, provàvelmente representado por material tanóide.

A estrutura do óvulo tem sido repetidamente estudada por diversos autores, o mesmo acontecendo com o seu desenvolvimento, nas diversas fases que constituem a macrosporogênese. Embora Houk (20) inicialmente tivesse afirmado que no óvulo de $C$. arabica $\mathrm{L}$. var. typica Cramer o nucelo e o integumento eram indistintos, contràriamente ao que demonstrara von Faber (12), pesquisas mais recentes conduzidas por Graner (18), Fagerlind (13), Joshi (23), e Mendes (28), demonstraram, de uma vez por tôdas, que estas duas zonas de tecido se apresentam bem distintas e separadas; o nucelo constitui-se de apenas uma camada de células estreitas

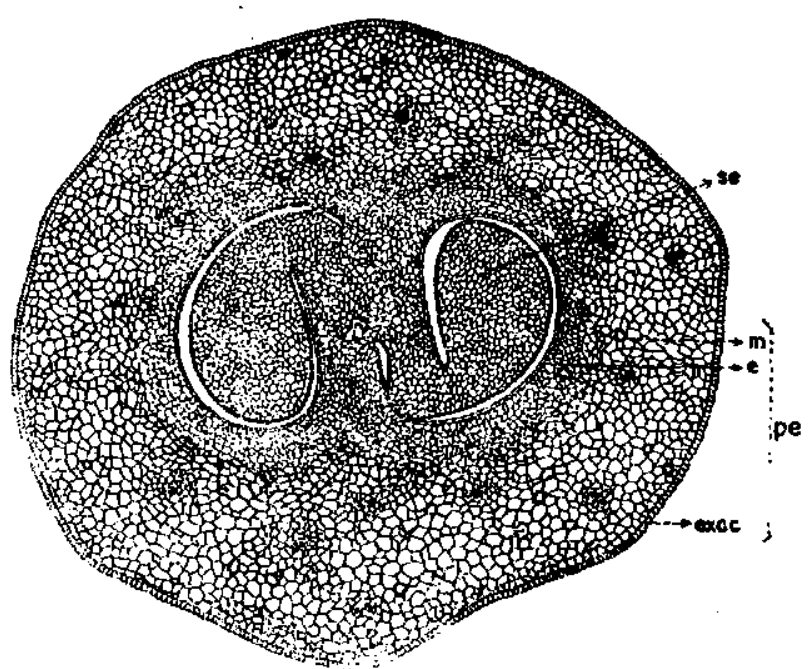

FiguRA 32. - Corte transversal do ovário fecundado ou fruto muito novo (30 X). $\mathbf{e}=$ endocarpo; exoc. $=$ exocarpo; $\mathbf{m}=$ mesccarpo; pe $=$ pericarpo; $\mathbf{S e}=$ semente. 
que rodeiam o macrósporo, e o único integumento, a primina, é espêsso, formado por diversas camadas de células. A macrosporogênese, é também normal, tal como constataram Graner $(18,19)$ e Mendes (28) ; segundo os mesmos autores a célula arquesporial sofre uma primeira divisão meiótica; uma das duas células formadas divide-se outra vez, equacionalmente, e a outra pode ou não

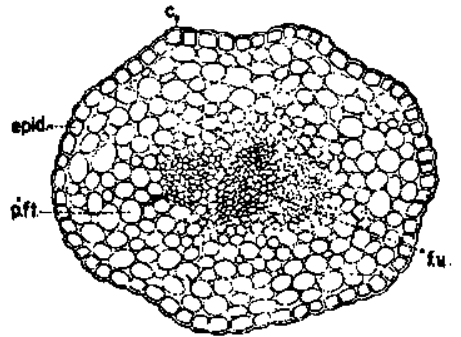

Figura 33. - Estilo segundo um corte transversal $(90 \mathrm{X}) . \mathbf{c}=$ cutícula; epid. = epiderme; f.v. $=$ feixe vascular; p.ft. $=$ parênquima fotossintético. passar por esta segunda divisão. Dêste modo formam-se três ou quatro macrósporos, um dos quais, o calazal, desenvolve-se em saco embrionário e os outros três degeneram e desaparecem. O saco embrionário é do tipo normal, monospórico, 8-nucleado, apresentando a oosfera flanqueada pelas duas sinérgidas no polo próximo à micrópila, as três antípodas no polo oposto e os dois núcleos polares na região central, que se fundem para formar o núcleo primário do endosperma.

O suprimento vascular do óvulo é representado por um só traço derivado do feixe da placenta; êste traço vascular único penetra pela base do óvulo através do funículo e atinge a região da calaza, de onde emite ramificações para o integumento.

O estilo terminal, estudado em cortes transversais (fig. 33), exibe um contôrno quase circular e mostra ser constituído de uma epiderme de células grandes, 5-6 camadas de tecido parenquimatoso e um feixe vascular central que, próximo à sua extremidade superior, se bifurca no sentido dos lobos estigmáticos. Êstes têm pràticamente a mesma constituição histológica do estilo, diferindo apenas pela epiderme interna, cujas células estão transformadas em papilas (pa), particularmente desenvolvidas nas bordas laterais dos lobos estigmáticos (fig. 34).

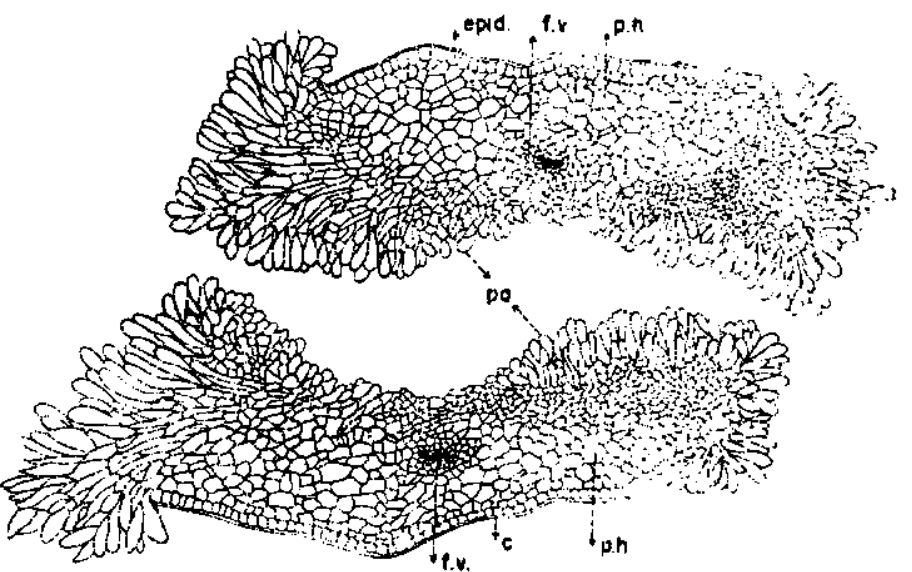

Figura 34. - Corte transversal dós lobos estigmáticos, vendo-se as papilas (pa) nas bordas internas e laterais $(60 \mathrm{X}) . \mathbf{c}=$ cutícula; f.v. = feixe vascular; p.h. = parênquima hialino; $\mathbf{p a}=$ papila.

Excepcionalmente são encontradas flôres que apresentam três lobos estigmáticos, o que pode ocorrer ou não em correlação com ovários triloculares. 
rizadas pelo grande espessamento das paredes de suas fibras e elementos traqueais.

Internamente, no limite com o endocarpo, e constituindo as últimas porções do mesocarpo, aparecem 1-2 camadas de células colunares, com tôdas as características de um tecido paliçádico, e à qual Menezes e Maniero (30) denominam "nova camada paliçádica", r'esponsável, na opinião dêsses autores, pelo armazenamento de grandes quantidades de água nos frutos maduros. Desde que essa zona de tecido parece ser presente no fruto de algumas espécies e variedades de cafeeiro e ausente em outras, a sua constatação reveste-se de importância como valioso característico de diferençação.

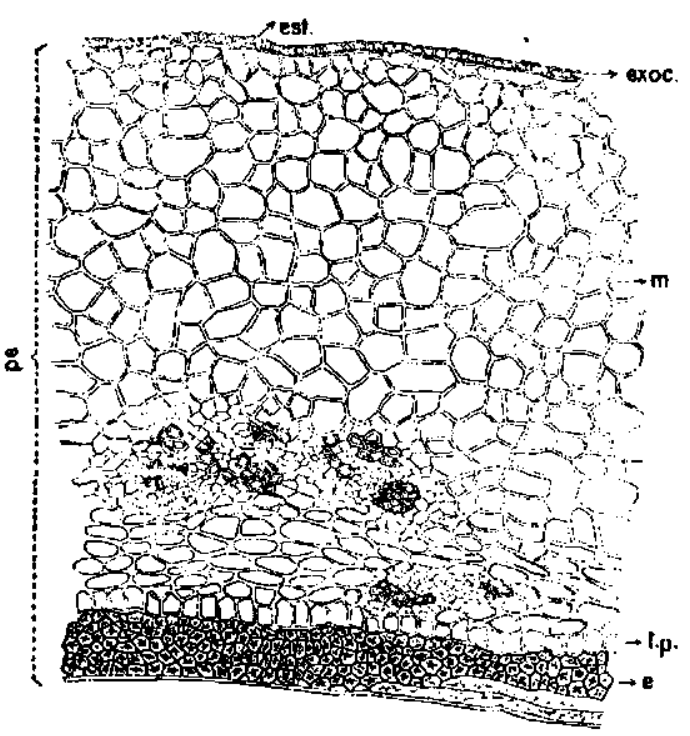

De tôdas as regiōes do pericarpo, contudo, é o endocarpo a que apresenta maiores modificações. No fruto já bem desenvolvido êste endocarpo está representado pelo "pergaminho da semente", de côr branco-acizentada ou brancoamarelada e de espessura aproximada de 100 micros, de textura flexível, resistente. $O$ estudo do pergaminho (e) em cortes transversais do fruto (fig. 37), ou mediante maceraçées, onde os seus elementos se apresentam dissociados e isolados (fig. 39), revela que os seus componentes săo fibras ( $\left.{ }^{(}\right)$de pa-
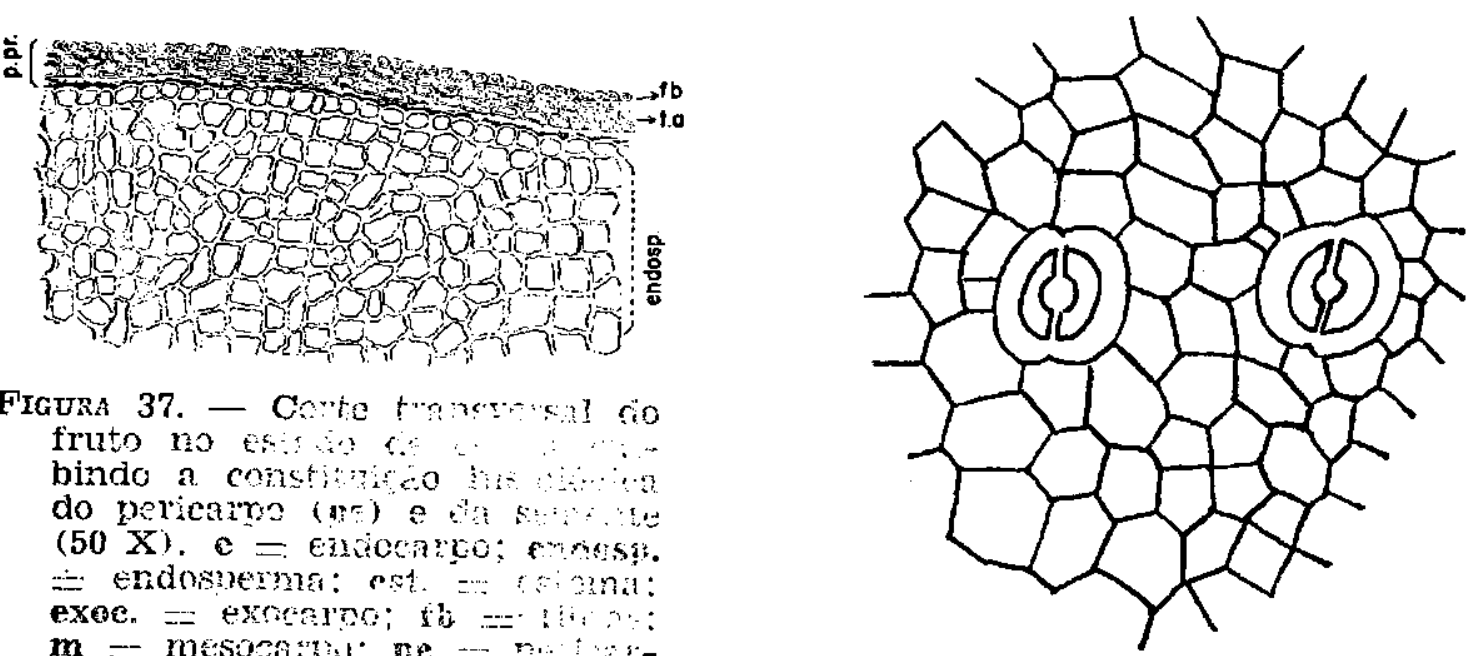

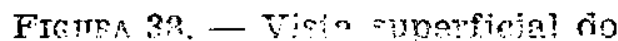
exoramo do "is nespondo os estomas $(400 \mathrm{X})$.

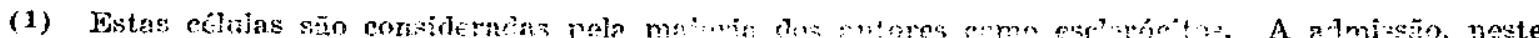

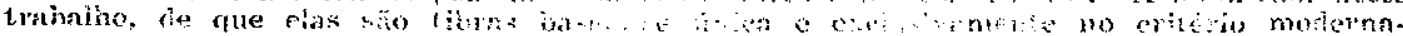

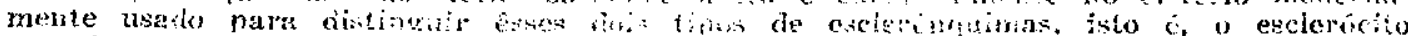
possui furma mass ou ments jocliamécica, e a fibra é caracterizada pelo seu comprimento bem maior que a largura. 
redes bastantes espêssas e luz ou lúmen muito reduzido, apresentándo pontuações do tipo ramificado. Essas fibras são fusiformes, geralmente de comprimento igual a muitas vêzes a largura medindo 350-750 micros de comprimento por 20-45 micros de largura e se dispõem compactamente unidas entre si, mediante uma substância que atua como cimento. Constituem elas 5-6 camadas de células em posições cruzadas ou oblíquas, o que confere ao endocarpo uma enorme resistência. A camada mais interna do endocarpo, a que reveste a cavidade da semente, é estreita e quase imperceptível.

Chevalier (7), na ilustração que faz da estrutura do pericarpo do fruto de $C$. arabica L., indica a existência de uma zona de tecido localizada entre as camadas mais internas do mesocarpo e o endocarpo; o referido autor designa esta região de zona gelificada (couche gelifiée) e atribui à mesma uma grande importância no preparo industrial do café (p. 39). Esta zona, que se mostra constituída por 3-4 camadas de células esclerenquimatosas dispostas à maneira de uma paliçada, é com tôda a certeza, a mesma assinalada por Ukers (36) e Winton (40), nos seus estudos sôbre a estrutura do fruto do café. Embora êsse tecido paliçádico possa ocorrer no fruto de certas espécies e variedades de Coffea, as presentes investigações confirmam amplamente a afirmação de

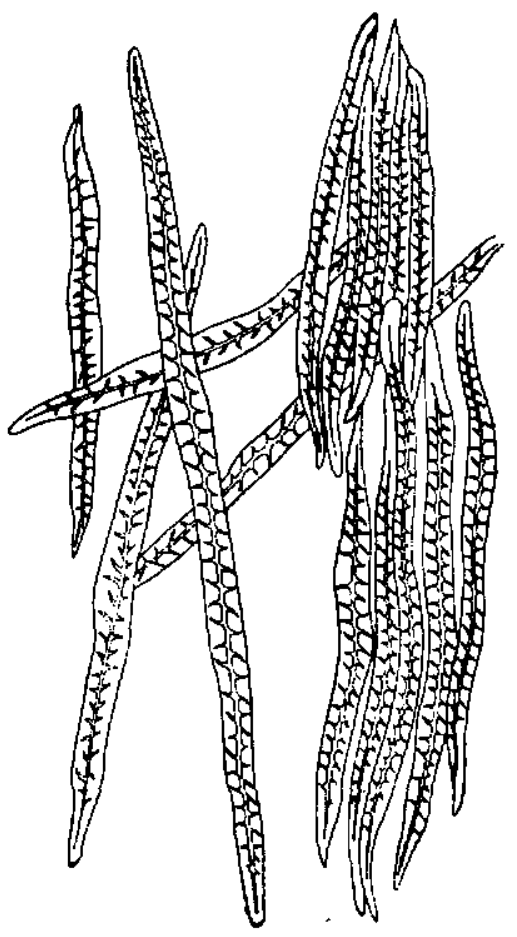

Figura 39. - Fibras isoladas do pergaminho da semente (endocarpo do fruto), com as suas paredes espêssas, pontuaçōes ramiformes e luz estreita $(90 \mathrm{X})$.

Menezes e Maniero (30), ou seja, a da não existência da referida zona no pericarpo do fruto de C. arabica L. var. typica Cramer.

\section{6 - SEMENTES}

As sementes do cafeeiro são plano-convexas, elíticas ou ovais, sulcadas longitudinalmente na face plana e constituem-se de embrião, endosperma e um envoltório, representado por uma película prateada ou espermoderma. Medições realizadas em um grande número de sementes revelam que na variedade typica elas medem $10-18 \mathrm{~mm}$ de comprimento por $6,5-9,5 \mathrm{~mm}$ de largura. As transformações do ovulo em semente foram minuciosamente estudadas por Houk (20, 21), Graner (18), Mendes (28), e outros autores, tendo sido questão de continuada controvérsia a existência ou não de um verdadeiro endosperma na semente. 


\section{1 - O ENVOLTÓRIO SEMINAL}

O envoltório seminal, pelicula prateada ou espermoderma (p.pr.), de cêrca de 70 micros de espessura, estudado em vista superficial (fig. 40), o que se consegue montando fragmentos dessa película diretamente em uma gôta de floroglucina em $\mathrm{HCl}$ e recobrindo-se com uma lamínula, apresenta-se constituído por numerosas células esclerenquimatosas, dispostas em diversas direções, a maioria delas paralela à superfície da semente. Estas células, fusiformes, consideradas geralmente como esclerócitos, mas que devido à sua forma prosenquimatosa podem ser encaradas como verdadeiras fibras ( $f b$ ),

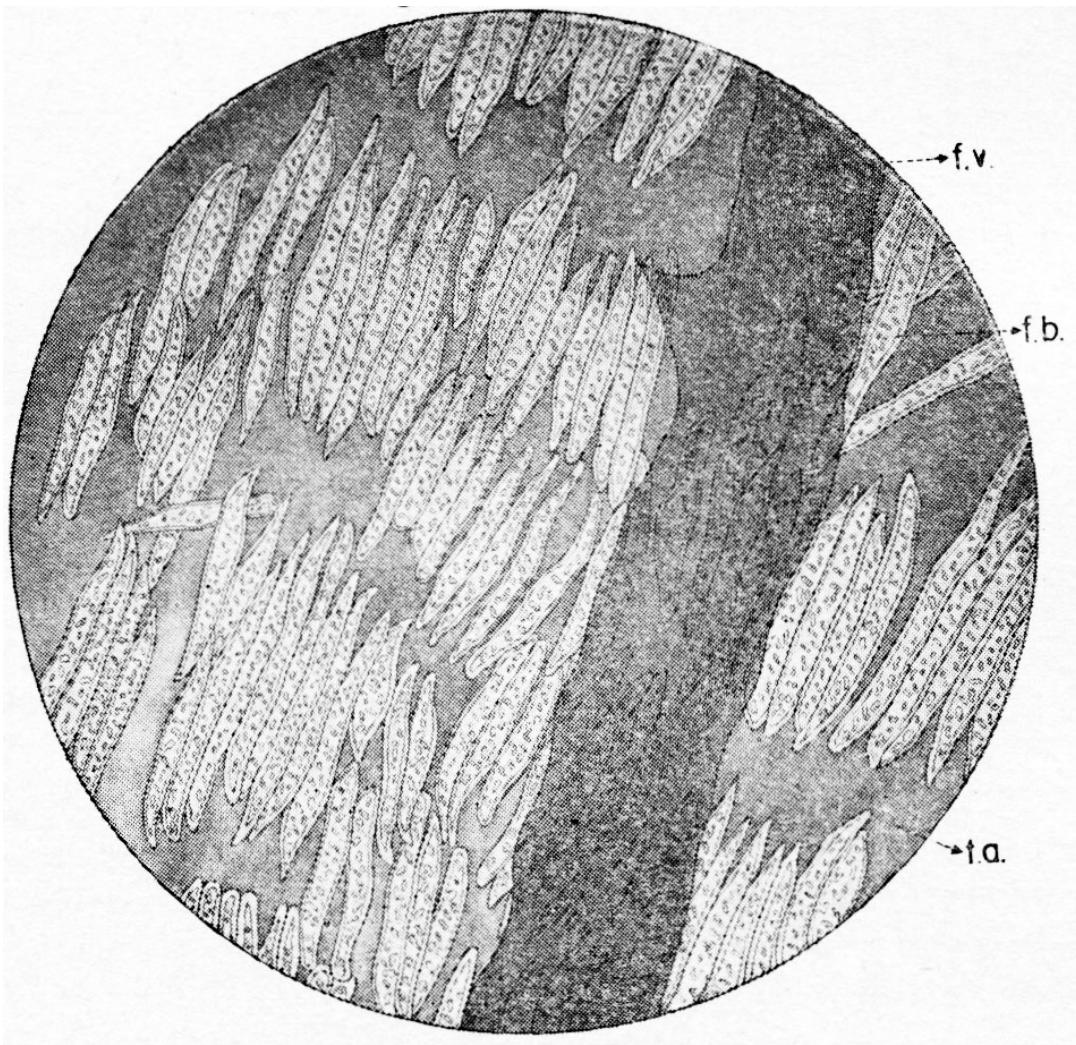

Figura 40. - Vista superficial da película prateada, vendo-se as fibras fusiformes (fb) sôbre um tecido amorfo (t.a.), e o seu suprimento vascular (f.v.) (90 X). formam um estrato que se assenta sôbre um conjunto de células hialinas, alongadas longitudinalmente ou amorfas devido ao dessecamento que sofreram e que são, portanto, células mortas, destituídas de protoplastos. Em cortes transversais da semente (fig. 37, p. pr.) percebe-se a constituição dêste tecido amorfo (t.a.) e, ainda mais, notase que a camada mais interna, que está diretamente em contato com o endosperma. da semente, tem as células completamente indistintas. As fibras e o tecido amorfo tiveram origem a partir do único integumento do óvulo, a primina, que era espêssa, sendo as fibras formadas pela camada mais externa de células dêste integumento.

As fibras fusiformes da película prateada apresentam no seu conjunto e na sua disposição uma certa semelhança com as fibras que constituem o pergaminho; contudo, são menores, de paredes menos espêssas, e as suas paredes exibem outro tipo de pontuações.

Essas fibras apresentam um comprimento de 180-320 micros e uma largura de 18-30 micros; suas paredes, espêssas, medem 
5-7 micros e apresentam um grande número de pontuações, 10-50 em cada face, que são do tipo simples, arredondadas, alongadas, ovóides etc..

O tamanho dessas fibras (relação comprimento/largura), a espessura das suas paredes e o número de pontuações nas paredes são característicos utilizados por Chevalier (7), na separação das espécies mais importantes de cafeeiros.

Finalmente, a película prateada exibe ainda um suprimento vascular (f.v.), representado pelas ramificações do feixe vascular que penetrou no óvulo pelo funículo e que à altura da calaza enviou ramificações para o integumento do óvulo (fig. 40).

\section{2 - O ENDOSPERMA}

O endosperma (endosp.), constituindo a quase totalidade do tecido da semente é de natureza triplóide $(3 n)$ e tem origem a partir da fusão do segundo gâmeta (n) do tubo polínico com o primeiro núcleo do endosperma $(2 \mathrm{n})$, completando o processo de dupla fertilização das angiospermas. Houk (20), estudando a transformação do óvulo afirmou que no cafeeiro a semente é desprovida de um verdadeiro endosperma e que a massa de tecido que constitui quase tôda a semente representava um "perisperma". Mendes (28), e outros pesquisadores, estudando o mesmo assunto forneceram as provas citológicas da existência do endosperma, o que fôra anteriormente demonstrado mediante bases genéticas por Krug e Carvalho (24). Segundo Mendes (28), o endosperma de C. arabica L. var. typica Cramer, que é sempre do tipo nucleado, pode ser observado na semente aproximadamente entre 21 e 27 dias após a abertura da flor; no seu desenvolvimento o número de núcleos aumenta consideràvelmente podendo atingir 90 e mesmo 120 , em flôres observadas 60 dias após a sua abertura.

Ainda segundo o mesmo autor, no desenvolvimento do óvulo em semente o nucelo é muito cedo absorvido e desaparece; os tecidos que constituem a primina formam inicialmente um "perisperma" - denominação imprópria (") - que é gradativamente absorvido pelo endosperma que se vai desenvolvendo, de tal modo que na semente madura o referido "perisperma", grandemente reduzido em espessura, está representado pela película prateada.

$\mathrm{Na}$ semente madura o endosperma apresenta-se como um tecido córneo, esverdeado ou côr-de-cana, de células poliédricas ou mais ou menos isodiamétricas, orientadas paralelamente à superfície ex-

(2) A nosso ver a impropriedade desta denominação reside no fato de atualmente haver urna tendência para se considerar como perisperma sòmente aquêles tecidos que tiveram origem a partir do nucelo. No entanto, no caso do cafeeiro Mendes (28) é o primeiro a admitir que o nucelo é absorvido e desaparece muito cedo, na transformação do óvulo em semente. 
terna, de paredes primárias, portanto celulósicas, excessivamente espêssas; a celulose representa também uma substância de reserva. A espessura dessas paredes celulósicas não é uniforme, pois nelas percebem-se regiões mais espêssas e estrangulamentos que lhe dão um aspecto moniliforme. As áreas menos espêssas representam campos-de-pontuações-primárias, nas quais Ayres (4) mediante técnica especial demonstrou a existência de plasmodesmas. Essa estrutura apresentada pelas paredes de células endospérmicas é considerada por Chevalier (7) como um dos característicos mais constantes exibidos pelos cafeeiros das seções Eucoffea e Mascarocoffea.

Um exame detalhado das diversas camadas de tecido endospérmico revela diferenças na sua estrutura, que provàvelmente estão ligadas a diferenças na composição química. Sementes completamente nuas, ao germinar mostram os cotilédones envolvidos numa espécie de capuz, constituído pelas camadas mais externas do endosperma e que muito se assemelha ao envoltório que recobre os cotilédones das plantinhas obtidas de sementes das quais não se retirou o pergaminho.

A camada mais externa de tecido endospérmico, aquela que se encontra diretamente revestida pela película prateada, é uniforme e tem o aspecto de uma epiderme, cujas células apresentam paredes espêssas (fig. 37) ; seguem-se diversas camadas de células poliédricas e ao nível da região mediana do endosperma, junto à cavidade embrionária (c.emb.), as células se tornam achatadas e alongadas paralelamente à superfície externa, constituindo um conjunto de camadas comprimidas que estabelecem uma região mais densa de células. A seguir, para o interior, as células reassumem a sua forma inicial. A zona densa marcaria o limite entre as duas porções de endosperma geralmente aceitas pelos autores: Moeller, citado por Ukers (36), designa respectivamente endosperma duro e endosperma mole às porções para o exterior e para o interior da zona densa, favorecendo assim a suposição de que realmente elas são diferentes quanto à sua composição química. Ao que parece, o embrião, ao se desenvolver, alimenta-se quase ùnicamente das camadas de endosperma mole situadas para o interior da cavidade embrionária, ao passo que as camadas exteriores, de endosperma duro, destacam-se e vão constituir o capuz que envolve os cotilédones da plantinha em desenvolvimento (fig. 41).

Algumas das células mais internas do endosperma possuem paredes primárias mucilaginosas e que, segundo Ukers (36), quando tratadas com água, desaparecem deixando visivel apenas a lamela mediana. Nestas condições a seção de tecido endospérmico exibe um aspecto peculiar.

Constituindo o endosperma a parte mais importante da semente, do ponto de vista da utilidade do cafeeiro, tem sido êle objeto de 
intensivos estudos no que diz respeito à sua composição. química. Segundo Winton (40), o endosperma encerra além de água, proteínas, os alcalóides cafeina e cofearina, óleos, açúcares, dextrina, pentosanas, celulose, ácidos derivados da cafeina, outros ácidos e componentes menores. A reserva gordurosa pode ser fàcilmente apreciada nas seções de endosperma, notando-se numerosas gotas esféricas de óleo em cada célula.

Pelo processo de torrefação altera-se grandemente a composição química do endosperma, já que êsse processo é uma destilação destrutiva acompanhada de desidratação, ocorrendo ainda várias reações de oxidação e redução. Sabe-se que durante esta operação a maior parte da água é eliminada, os açúrares são transformados em caramelo, os ácidos

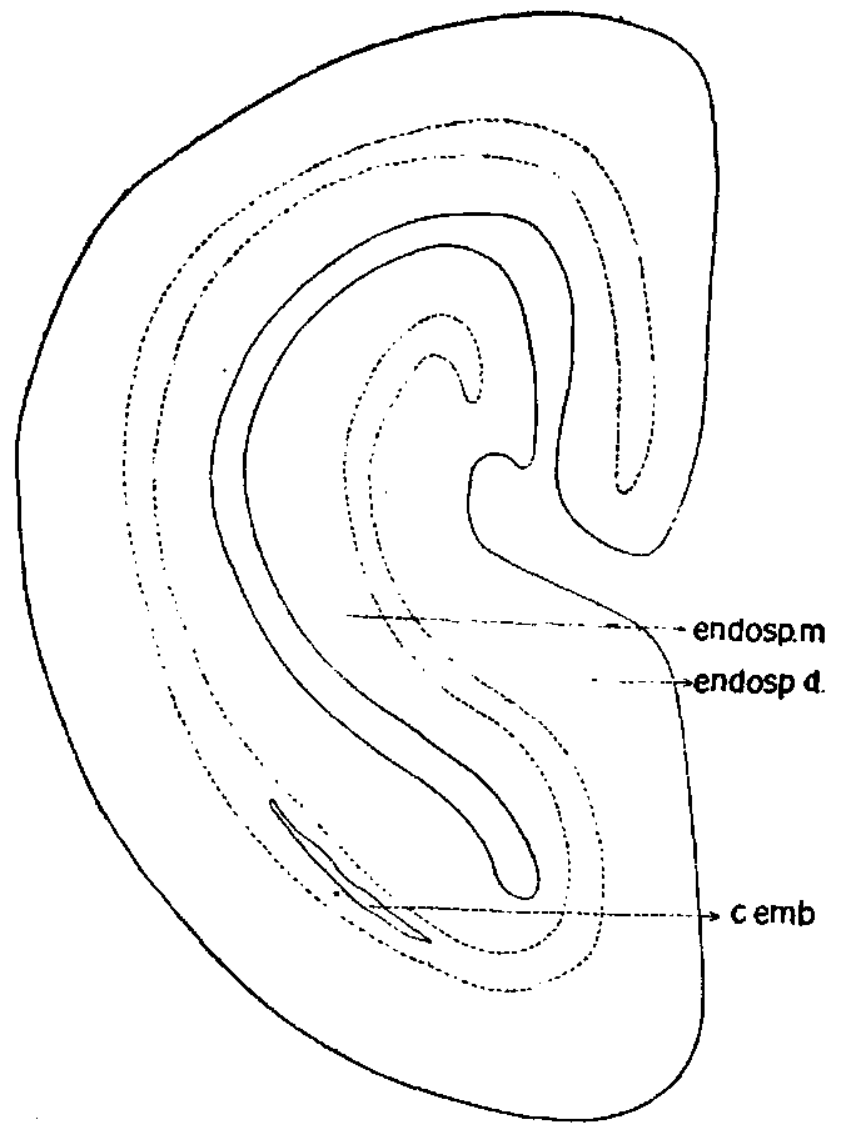

Figura 41. - Corte transversal da semente, indicando a cavidade embrionária (c.emb.), que estabelece o limite entre as camadas de endosperma duro (endosp.d.), para o exterior, e as de endosperma mole (endosp.m.), para 0 interior $(40 \mathrm{X}$ ). derivados da cafeina reduzem-se à metade, bem como há perda no teor da cafeina. Como resultado de tôdas essas reações desenvolve-se no pó de café o aroma, que é um dos seus principais atributos.

$\mathrm{Na}$ face plana das sementes, o endosperma apresenta um sulco longitudinal, cuja profundidade e forma são consideradas de importância por De Wildeman (39), para caracterizar espécies e variedades de cafeeiros. Cortes transversais da semente evidenciam que tanto o endocarpo do fruto (pergaminho) como a película prateada invaginam-se na região do sulco, estando presentes no seu interior.

\section{3 - EMBRIÃO}

O embrião de Coffea arabica L. var. typica Cramer, pequeno e localizado na base da semente, na sua face convexa, é representado por um hipocótilo e dois cotilédones cordiformes. A diferençação do embrião se verifica relativamente tarde; de acôrdo com Mendes (28), o zigoto ou célula-ôvo permanece em estado de repouso por 60-70 dias, ao cabo dos quais sofre a primeira divisão da qual resultam duas células irmãs; a apical torna-se a dividir outra 


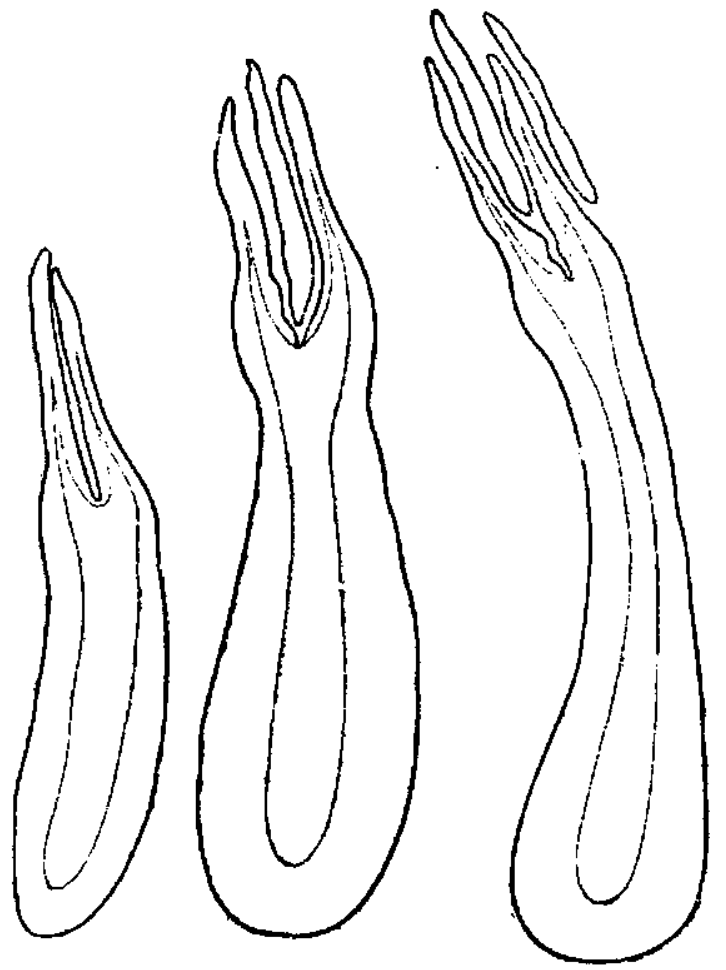

Figura 42. - Cortes longitudinais de três embrióes, respectivamente com 2,3 e 4 cotilédones ( $55 \mathrm{X}$ ).

vez transversalmente, formando um proembrião tricelular; a célula mais apical destas três é que, a seguir, se divide longitudinalmente, e essa primeira divisão longitudinal marca o início da diferençação do embrião pròpriamente dito, ao passo que as outras células vão constituir o suspensor. Aproximadamente 150 dias após a abertura das flôres, quando o endosperma já se encontra perfeitamente desenvolvido, tem início a diferençação dos cotilédones.

Normalmente os cotilédones (cot.) cordiformes e justapostos são em número de dois, porém, podem ser encontrados embriōes com três e quatro cotilédones (fig. 42). Compõem-se êles de epiderme com estomas (fig. 43), mesofilo homogêneo, portanto sem distinção de parênquimas pa-

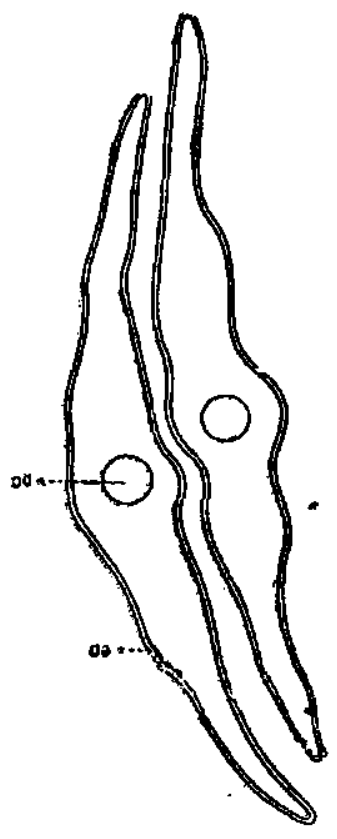

Figura 43. - Corte transversal dos cotiledones (55 $\mathrm{X})$. ep = epiderme; pc = procâmbio. liçádico e esponjoso, e apresentam, no centro, o seu suprimento vascular na forma de um feixe procambial (pc).

Igualmente, o hipocótilo (figs. 44 e 45), que em seção transversal exibe um contôrno elítico ou quase circular, constitui-se de epiderme, córtex não diferençado, procâmbio e medula não diferençada.

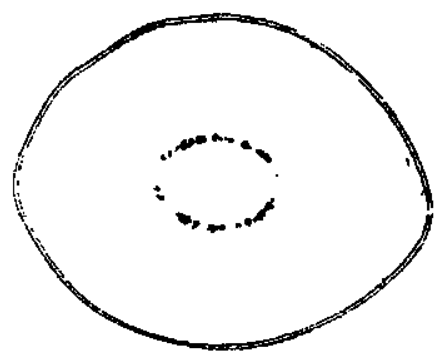

Figura 44. - Desenho esquemático do hipocótilo segundo um c orte transversal (55 X).

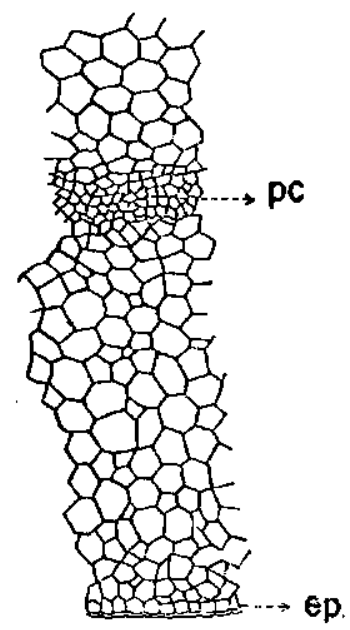

Figura 45. - Detalhes histológicos do corte da figura $44 \quad(109$ $\mathrm{X}): \mathbf{e p}=$ epiderme; pc $=$ procâmbio. 


\section{7 - CONCLUSÕES}

O estudo da anatomia e do desenvolvimento ontogenético de Coffea arabica L. var. typica Cramer revelou que a estrutura do cafeeiro é bastante normal, não tendo sido assinaladas diferenças estruturais-acentuadas em relação a outras espécies rubiáceas de constituição histológica já conhecida.

A raíz é tìpicamente proto-estélica, exárquica e poliárquica, apresentando mais comumente $6,7,8,9$ e 11 feixes de xilema e floema primários. Foi constatado que o número dêstes feixes varia não sòmente nas raízes de diferentes indivíduos, como também, entre as raízes de um mesmo îndivíduo.

O câmbio vascular torna-se visível nos cortes praticados cêrca de $5 \mathrm{~cm}$ do ápice da raíz, sendo inicialmente formado a partir de células parenquimatosas situadas entre os feixes de xilema e floema primários; posteriormente, células pericíclicas localizadas na borda externa de cada feixe liberiano participam também da formação do câmbio vascular.

A observação de um periderma nas raízes, torna-se muito difícil devido, sobretudo, ao aspecto fragmentado e dilacerado dos tecidos epidérmicos e corticais que se desprendem; contudo, é certo que o felógeno ou câmbio suberoso tem seu início a partir de divisões tangenciais de células do periciclo e que repetidas divisões das suas células, segundo êste mesmo plano de divisão, podem conduzir à formação de um periderma de espessura variável entre 90-100 micros.

A gema do caule, a partir da qual têm origem todos os tecidos do caule e da fôlha, apresenta-se com forma e dimensões típicas das gemas dos angiospermas, isto é, assume a forma de uma pequena elevação e, quanto ao seu tamanho, as dimensões se mostram muito variáveis dependendo de ser a gema dormente ou estar em atividade. A sua estrutura zonada, interpretada sob a luz da teoria de Schmidt, revela a existência de duas ou três camadas na túnica envolvendo o massiço central de células, que constitui o corpo.

A estrutura primária do caule é tìpicamente sifono-estélica e endárquica e tem uma duração relativamente curta, já que uma zona cambial pode ser observada nos cortes transversais praticados cêrca de $2,5 \mathrm{~cm}$ do ápice. A presença de cristais prismáticos de oxalato de cálcio em muitas células dos raios medulares tem sido considerada como um característico taxonômico para as espécies de cafeeiros da seção Eucoffea. Sòmente estudos cuidadosos e demorados com outras variedades de $C$. arabica $\mathrm{L}$. é que poderão indicar a sua utilidade ou não para a caracterização de variedades de cafeeiros.

O câmbio suberoso ou felógeno, visível em cortes realizados aproximadamente a $4,5 \mathrm{~cm}$ da gema apical, é formado a partir de 
células que constituem as camadas mais internas do parênquima cortical e da sua atividade resulta um periderma de 70 micros de espessura, aproximadamente.

Nas fôlhas são encontradas as estruturas que, de um modo mais particular, caracterizam as espécies do gênero Coffea e de outros gêneros mais ou menos afins das rubiáceas. Essas estruturas são as domácias, que apresentando uma certa variabilidade na sua constituição, fornecem diversos característicos cujo valor taxonômico constitui um ponto de discussão, o que igualmente acontece com relação ao seu significado fisiológico. Neste último particular é evidente, à luz dos presentes estudos, que a denominação domácia deve ser aplicada sòmente às estruturas localizadas na fôlha dos cafeeiros e outras rubiáceas, no ângulo formado pela nervura principal com as secundárias, e não deve ser utilizada para designar certas nodosidades esparsas nas fôlhas de diversas espécies dos gêneros Pavetta e Psychotria, nodosidades estas onde se alojam bactérias simbióticas que têm a faculdade de fixar diretamente o nitrogêrio atmosférico.

A inflorescência do cafeeiro é do tipo homotático composto, e o pequeno desenvolvimento dos eixos laterais é o responsável pelo aspecto condensado da mesma, de modo a conferir-lhe a denominação de glomérulo. A seqüência do desenvolvimento ontogenético dos diversos verticilos florais é a que normalmente tem sido encontrada para outras espécies. A microsporogênese é relatada como normal, na literatura especializada. Numerosos são os trabalhos realizados sôbre a estrutura do óvulo, bem como sôbre seu desenvolvimento nas diversas fases da macrosporogênese. À luz destas investigações mais recentes ficou comprovado que no óvulo do cafeeiro o nucelo e o integumento se apresentam como entidades distintas, o primeiro constituído de uma só camada de células, e a primina, único integumento, é espêssa, formada de várias camadas de células. Revelam ainda estas investigações que a macrosporogênese é normal, e que dos 3 ou 4 macrósporos que podem se formar, somente o calazal é que se desenvolve em saco embrionário e os demais degeneram e morrem. Por sua vez, o saco embrionário assim formado é do tipo normal, 8-nucleado.

Os frutos estudados em diversas fases do seu desenvolvimento mostraram possuir uma estrutura bem normal em suas diferentes porções. Torna-se oportuno assinalar a ocorrência de estomas por entre as células que constituem o exocarpo, fato êsse que já foi objeto de dúvidas, como também a existência de um tecido palicádico no mesocarpo, representado por 1-2 camadas de células colunares, diretamente em contato com as fibras do encodarpo.

O endocarpo está representado por 5-7 camadas de células e vai constiuir no fruto maduro o chamado pergaminho da semente. Desta maneira, o nosso ponto de vista contraria a opinião de Che- 
valier (7), de que o endocarpo seria representado apenas por uma camada de células, a mais interna do pericarpo, e correspondente à epiderme interna da cavidade ovariana, e que o pergaminho da semente ("parche") seria formado a partir das camadas mais internas do mesocarpo.

Os elementos que constituem o pergaminho da semente, pela natureza das suas paredes e pela sua forma prosenquimatosa, mostram ser verdadeiras fibras, e os seus diversos característicos de tamanho, espessura das paredes, número de camadas etc., deverão ser levados em consideração como possíveis característicos taxonômicos.

As presentes investigações não revelaram a existência, no pericarpo do fruto da variedade typica, da zona gelificada ("couche gélifiée") assinalada e descrita por Chevalier (7), mas, como foi dito anteriormente, encontrou-se a zona de tecido a que Menezes e Maniero (30) fazem menção em seus trabalhos e à qual denominaram "nova camada paliçádica".

Do estudo da anatomia das sementes conclui-se que no envoltório seminal, espermoderma ou película prateada estão localizados os característicos mais importantes a serem utilizados na caracterização das espécies e variedades de cafeeiros. Êstes característicos dizem respeito às dimensões das fibras que constituem a referida película, à espessura das suas paredes e ao número de pontuações nestas paredes etc..

Contrariando a suposição inicial de Houk (20) de que na semente do cafeeiro não havia um verdadeiro endosperma, diversos investigadores demonstraram por meio de provas citológicas e genéticas a existência dêsse endosperma, que é do tipo nucleado. Contestação é feita, contudo, no presente trabalho, ao uso da denominação "perisperma" para designar os restos dos tecidos da primina, que na semente madura estão representados pela película prateada.

A admissão por parte de outros autores, como por exemplo Moeller, citado por Ukers (36), de que também do ponto de vista da composição química o endosperma se apresenta heterogêneo nas suas diversas camadas, de tal modo que se torna possível considerar-se duas porções diferentes, uma mais interna, de endosperma mole, e outra mais externa, de endosperma duro, é amplamente confirmada pelos característicos anatômicos dessas diferentes porções e pelo fato de plantinhas obtidas a partir de sementes completamente nuas trazerem os cotilédones recobertos por uma espécie de capuz, que seria constituído apenas pelas camadas de endosperma duro.

O estudo da forma e profundidade do sulco longitudinal que ocorre no endosperma, na face plana da semente, concuzido em grande número de variedades e espécies de cafeeiros, deverá indicar se os mesmos representam ou não característico de algum valor taxonômico. 


\section{ANATOMY AND ONTOGENETICAL DEVELOPMENT OF COFFEA ARABICA}

\section{VAR. TYPICA CRAMER}

\section{S U M M A R Y}

The knowledge of the anatomy of Coffea arabica $\mathrm{L}$. var. typica Cramer should be considered as a basic contribution to the comparative study of the anatomy of coffee species and varieties cultivated in the State of São Paulo, Brazil. The detailed investigations carried out on the vegetative and reproductive organs of the coffee plant revealed the following.

The roots at the end of the primary growth present a protostelic, poliarch $(6,7,8,9,11$ primary xylem bundles), and exarch structure, the following tissues or zone of tissues being visible: root cap, epidermis, exodermis, cortex, endodermis, pericycle, primary phloem and primary xylem. This primary growth has a very short duration and is very soon followed by the secondary growth, formed from a vascular cambium which makes its first appearance in a region localized approximately $5 \mathrm{~cm}$ from the root apex. Phellogen arises first in the pericycle and later in phloem and gives origin to a relatively thin periderm; this protective layer replaces the epidermis that is gradually killed and sloughs away. Lateral roots originate from pericyclic cells situated at the protoxylem outer edges.

The origin of all stem tissues, as well as those of the leaves, can be traced back to a dome-shaped shoot apex, which measure 220-360 microns in diameter and 48-120 microns in its major height; this shoot apex interpreted under the terms of Schmidt's theory shows to possess a tunica composed of two or three cell layers, and a corpus, represented by a central core of irregularly arranged ceils. Differentiation of meristematic tissue initiates at the distance of 800-900 microns from the shoot apex, but the complete primary tissue differentiation is only achieved in a region situated $2.5 \mathrm{~cm}$ from the shoot apex. Stem cross sections at this level exhibit the following tissue zones: epidermis, angular collenchyma, cortical parenchyma, pericycle, primary phloem, primary xylem and pith. No distinct endodermis is visible.

The vascular cambium, firstly visible in a region distant $2.5 \mathrm{~cm}$ from the shoot apex, originates from procambial cells localized between the xylem and phloem, being at the beginning only fascicular; the cells of the primary rays undergo cambiform meristematic activity, and interfascicular cambium is thereby formed between the vascular bundles. Following a centripetal differentiation the cambial derivatives give rise to a continuous band of secondary xylem and secondary phloem.

Older stem cross sections present a periderm which is about 70 microns thick. Cork cambium arises from the innermost cells of cortex and produces cork externally and phelloderm internally.

Petiole presents a tricyclic structure, exhibiting three vascular bundles, the major one corresponding to the mid-rib; all the bundles show a normal orientation of the xylem and phloem tissues. Secondary vascular bundles are also present towards the wings of the petiole cross section.

The structure of foliage blade is that of typical leaves of dorsiventral symmetry. At an early stage the blade consists of seven layers of relatively undifferentiated cells.

At maturity, just one layer of palisade parenchyma and ten to twelve layers of spongy cells are present. Upper epidermis is uniseriate and formed only by epidermal cells proper; uniseriate lower epidermis exhibits these cells sind stomata which are of the rubiaceous type, being formed by two guard cells and two subsidiary cells. Remarkable is the occurrence on the lower epidermis of certain structures called domatiae; the constancy of these structures on the lower epidermis of the leaves of Coffea and a few other rubiaceous genera has been considered an important taxonomic characteristic for genera identification. On the other hand, the domatia localization, shape, size and constitution, as well 
as the presence or absence of stomata on their outermost cell layer or the presence or absence of hairs on the borders of the domatia aperture, have shown to be important characteristics to be utilized in the differentiation of Coffea species and varieties.

In Coffea arabica $\mathrm{L}$. var. typica Cramer the domatiae are localized at the very angle formed by the secondary veins with the mid-rib, have a vesicular shape and open externally through an elliptical or round pore which measures 200-260 microns in diameter; the borders of the pore are nearly glabrous, a few hairs appearing only in a region distant from the borders; very few stomata are also present on the outermost cell layer of the domatia.

Stipule structure is similar to that of foliage blade, but no differentiation between palisade parenchyma and spongy cells is apparent.

The inflorescence is of the homotatic type, the lateral axes being very short; consequently the flowers are disposed in axilar glomerules; bracteoles are in number of two pairs for each flower set, being respectively lanceolate and triangular, and presenting the same structure of the stipules.

Calyx is very rudimentary; the sepals resemble the leaves anatomically, and present only a trace supply; the petals are united in a tube forming a salver-shaped corolla, presenting a single vascular trace each. Stamens are epipetalous and have also a single trace as vascular supply; the anthers are two-celled, opening lengthwise. At maturity each anther exhibits in cross section four pollen-sacs, surrounded by an uniseriate epidermis, two fiber layers and a narrow strip of tapetum vestiges. Microsporogenesis is reported to be normal by several authors. Pollen grains are numerous, globose, with a very thick, smooth, and 3-4-sulcate exine.

Pistil is represented by an inferior ovary, terminal style and two stigmatic branches. Ovary is normally two-celled, each one bearing a single anatropous ovule on a central placenta; funicle is very short, and the embryo-sac is of the normal type, monosporic, 8-nucleate. Anatomically the ovary shows to be formed by uniseriate epidermes, the outer one presenting stomata; between the epidermes there is parenchymatous tissue, and distributed in this thick parenchyma there are 2 or 3 concentric vascular bundle series.

The coffee fruit is a drupe, containing normally two seeds; exceptionally there is the occurrence of three or more seeds in the cases of tri-celled or pluri-celled ovaries, or through false polyembryony when bi-celled ovaries present more than one ovule in each cell. On the other hand, by abortion of an ovule one-seeded fruit may be formed (peaberry). Ripe fruits have a fleshy and thick pericarp. Fruit development brings about a series of chemical and morphological modifications that lead to a reduction in the thickness of pericarp, from $1.5 \mathrm{~mm}$ in ripe fruits to 0.4 in dried fruits. Exocarp is represented by a single layer of hardened and lignified cells, with scattered stomata. Mesocarp is formed by several layers of polyhedric, large and lignified cells, the innermost of which are somewhat compressed and flattened. Amidst these cells are visible the vascular bundles showing a great amount of fibers. Endocarp is about 100 microns thick and constitutes in the ripe fruits the so-called "seed parchment". Studied in cross section the endocarp shows to be formed by 5-6 layers of intercrossing strong fibers, what gives this zone of tissue an extraordinary strength. Maceration allows the detailed examination of the individual fibers which measure 350-370 microns in length by 20-45 microns in transverse diameter. The cell walls are very thick and provided with ramiform pits; cell lumen is almost sccluded.

The coffee seeds or coffee beans are elliptical or egg-shaped, plane-convex, possessing a longitudinal furrow on the plane surface. Seed coat is represented by the so-called "silver skin", which ontogenetically originates from the primine, the single ovule integument. This seed coat is about 70 microns thick and anatomically shows to be constituted by an outer layer of fibers somewhat similar to the endocarp fibers; they are, however, shorter, measuring the longest ones 
180-320 microns in length and 18-30 microns in transverse diameter. Their thick walls are provided with round, elliptical, or elongated simple pits. The size of these fibers, the thickness and number of pits on their walls are considered by Chevalier as important taxonomic characteristics for the differentiation of Coffea species.

Completing the silver skin structure there are several layers of amorphic parenchyma tissue, and a layer of indistinct cells which originate from the innermost cell layer of the primine. On the other hand, the fibers had their origin from the outermost cell layer of the primine.

Endosperm is formed by polyhedric cells of very thick cellulosic walls, functioning the cellulose in this case as food storage. With the aid of a special technique plasmodesmata can be detected in the primary-pit-fields of the endosperm cell walls.

The endosperm tissue seems to present differences in the structure and chemical composition of its various layers; thus, at the level of the embryo cavity the cells are flattened and elongated constituting a region which probably desintegrates during embryo development. The outer layers represented by hard endosperm slough away as a cap that involves the cotyledons of seedlings obtained from completely naked seeds. This cap resembles the seed parchment in gross morphology. The inner layers are considered soft endosperm. As to the chemical composition, the endosperm cells besides water, contains protein, the alkaloicis cafeine and coffearine, oil, sugar, dextrins, pentosans, cellulose, caffetannic acids, minerals, various acids and minor constituents.

The small embryo, localized at the bottom of the seed, on its convex surface is represented by an hypocotyl and two adherent cordiform cotyledons. Very seldom there is the occurrence of embryo with 3 or 4 cotyledons.

\section{LITERATURA CITADA}

1. ACCORSI, W. R. A ocorrência das células anexas dos estômatos na família Rubiaceae. I. Solo, Piracicaba 33:[27]-37. 1942.

2. __ A ocorrência das células anexas dos estômatos na família Rubiaceae. II. Ann. Esc. Agric. Queiroz 1:[157]-175. 1944. (Separata)

3. ___ A cocirncia das células anexas dos estômatos na família Rubiaceae. III. Ann. Esc. Agric. Queiroz 4:[411]-436. 1947. (Separata)

4. AYRES, G. C. M. A ocorrência de plasmodesmas no endosperma de Coffea arabica L. var. typica Cramer. Bragantia 13:[281]-285. 1954.

5. BAILEY, I. W. The anatomical approach to the study of genera. Chron. bot. 14:121-125. 1953.

6. BITANCOURT, A. A. Estrutura anatômica das principais plantas cultivadas no Brasil. Rio de J., Emp. Ind. O Norte, 1923. 43 p. (Tese) [Microfilme copiado]

7. Chevalier, AUGUSTE. Les caféiers du globe. III. Systematique des caféiers et faux-caféiers, malaủies et insects nuisibles. Paris, Lechevallier, 1947. 356 p. (Encyclopédie biologique n. 28)

8. DEDECCA, D. M. Aspectos anatômicos da variegação na fôha do cafeeiro. Bragantia 16:[389]-410. 1957.

9. DER MEULEN, A. VAN. Over den Bouw en de periodieke ontowikkeling der' Bloemknoppen bij Coffea-soorten. Kon. Ned. Akad. Wet. Verh. 38:1-128. 1929.

10. DUBARD, M. Les caféiers sauvages de Madagascar. Bull. Mus. Hist. nat., Paris 13:280-282. 1907.

11. FABER, F. C. VON. Das erbliche Zusammenleben von Bakterien und tropischen Pflanzen. Jb. wiss. Bot. 51:243-264. 1912. 
12. Morfologische-physiologische Untersuchungen an Blüten von Coffea-Arten. Ann. Jard. bot. Buitenz. 2:59-160. 1912.

13. FAGERLIND, G. Perisperm oder Endosperm bei Coffea? Svensk Botanisk Tidskr. 33:303-309. 1939.

14. FRANCO, C. M. Relation between chromosome number and stomata in Coffea. Bot. Gaz. 100:817-827. 1939.

15. Sôbre compostos fenólicos no café. J. Agron., Piracicaba 2:131-138. 1939 .

16. ___ \& INFORZATO, R. O sistema radicular do cafeeiro nos principais tipos de solos do Estado de São Paulo. Bragantia 6:[443]-478. 1946.

17. FREIRE, C. V. Contribuição ao estudo histológico dos cafeeiros no Brasil. Rev. Dep. Café, Rio de J. 3:987-991. 1934.

18. GRANER, E. A. Embriogênese de Coffea. I. Desenvolvimento do óvulo em Coffea arabica L.. In Reunião sul-americana de Botânica, 1.a, Rio de J., 1938. Anais. Rio de Janeiro, Ministério da Agricultura, 1939. v. 3 p. 193-202.

19.

Megasporogenesis in Coffea arabica L. Arch. Inst. Biol. veg., Rio de J. 3:69. 1936.

20. HOUK, W. G. Endosperm and perisperm of coffee with notes on the morphology of the ovule and seed development. Amer. J. Bot. 25:56-61. 1938.

21. The ovule and seed of Coffea arabica L.. Science 83:464-465. 1936.

22. JACKSON, B. D. Glossary of Botanic Terms. Londres, Duchworth, 1928. iv, $481 \mathrm{p}$.

23. JOSHI, A. C. A note on the morphology of the ovule of Rubiaceae with special reference to Cinchona and Coffea. Curr. Sci. 7:236-237. 1938.

24. KRUG, C. A. \& CARVALHO, A. Genetical proof of the existence of coffee endosperm. Nature 144:515. 1939.

25. —_ MENDES, J. E. T. \& CARVALHO, A. Taxonomia de Coffea arabica. Descriçāo das variedades e formas encontradas no Est. de São Paulo. Campinas, Instituto agronômico, 1939. 59 p. (Bol. Tecn. n. 62)

26. LUNDSTrofM, A. E. Pflanzenbiologische Studien. II. Die Anpassungen der Pflanzen an Tiere. Domatienfürende Pflanzen. Nova Acta Soc. Sci. upsal. 13:1-88. 1887.

27. MARIANT, M. J. Les caféiers. Structure anatomique de la feuille. Paris, Lons-le-Saunier, 1908. 140 p. [Microfilme copiado]

28. MENDES, A. J. T. Cytological observations in Coffea. IV. Embryo and endosperm development in Coffea arabica L.. Amer. J. Bot. 28:784-798. 1941.

29. Observações citológicas em Coffea. XV. Microsporogênese em C. arabica L.. Bragantia 10:[79]-87. 1950.

30. MENEZES, J. B. F. (júnior) \& MANIERO, J. Sôbre um método microscópico para contagem de cascas no café em pó. Rev. Inst. Lutz 11:13-47. 1951.

31. METCAIFE, C. R., CHALK, L., CHATTAWAY, M. M. [e outros] Anatomy of the dicotyledons. Oxford, Clarendon Press, 1950.1500 p. 2 v.

32. PENZIG, O. \& CHIABRERA, C. Contributo alle conoscenza delle planta acarofile. Malpighia 18:429-498. 1903.

33. RANDOLPH, L. F. A new fluid and a revised schedule for the paraffin method in plant cytology. Stain Tech. 10:95-96. 1935. 
34. SANTOS, CLOVIS F. O. Contribuição ao conhecimento dos nectários de algumas espécies da flora apícola. Piracicaba, Escola Superior de Agricultura "Luiz de Queiroz", 1954. 66 p. (Tese). [Mimeografado]

35. SOLEREDER, H. Systematic anatomy of the dicotyledons. Oxford, Clarendon Press, 1908. 1183 p.

36. UKERS, W. H. All about coffee. 2. ed. New York, The Tea \& Coffee Trade Journal Company. 1955. $818 \mathrm{p}$.

37. VALLE, E. P. Família das Rubiáceas; estudo geral aplicado. Belo Horizonte, Empr. Queiroz Breyner Ltda., sd.. 120 p. (Tese)

38. VAROSSIEAU, $W$. W. On the development of the stem and the formation of leaves in Coffea species. Leiden,Brille, 1940. $88 \mathrm{p}$. (Tese).

39. WILDEMAN, 亡. DE. Etudes sur le genre Coffea L.. Classification, caractères morphologiques, biologiques et chimiques, sélection et normalization. Bruxelles, Palais des Académies, 1941. 496 p. (Fondation Agathon de Potter n. 2)

40. WINTON, A. L. \& WINTON, K. B. The structure and composition of foods. New York, John Wiley, 1939.580 p. v. 7. 


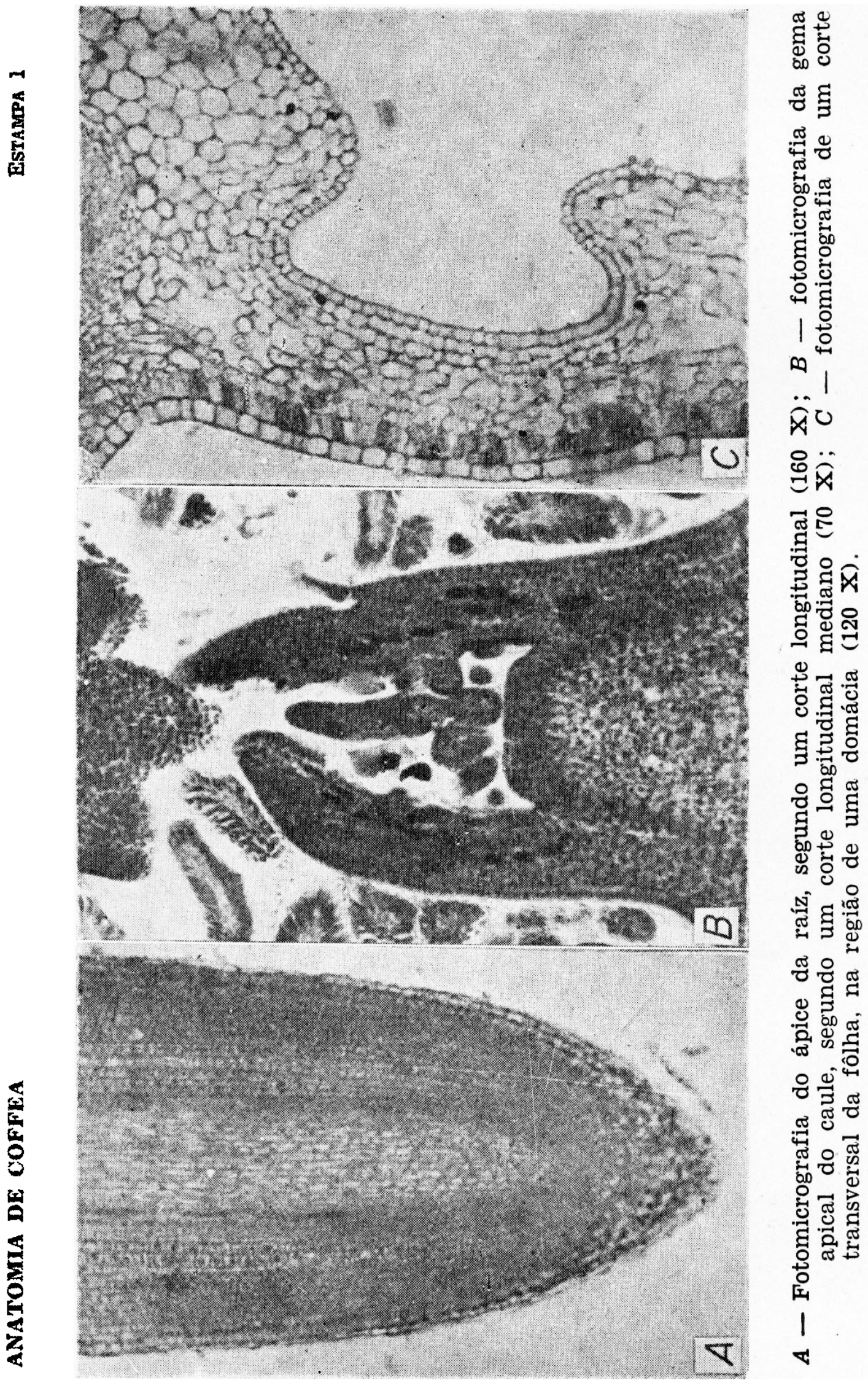

